Supplement of Nat. Hazards Earth Syst. Sci., 18, 869-887, 2018

https://doi.org/10.5194/nhess-18-869-2018-supplement

(c) Author(s) 2018. This work is distributed under

the Creative Commons Attribution 3.0 License.

(c) (1)

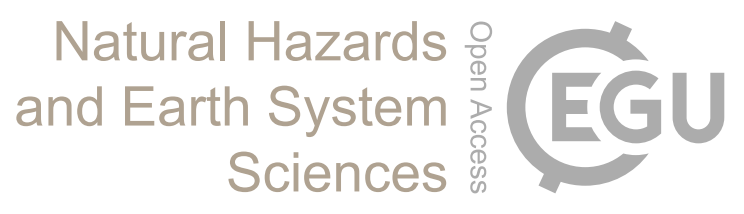

Supplement of

\title{
Modeling the influence of snow cover temperature and water content on wet-snow avalanche runout
}

\section{Cesar Vera Valero et al.}

Correspondence to: Cesar Vera Valero (cesar.vera@slf.ch)

The copyright of individual parts of the supplement might differ from the CC BY 3.0 License. 


\section{Supplement A}

The following pages show the avalanche calculations performed with the thermomechanical model RAMMS and the guideline-VS model for the 12 case studies. In each figure, the measured release (orange polygon) and deposits (violet polygon) areas are shown. The color bar denotes deposits height (i.e., flow height in last time step $>20 \mathrm{~cm}$ ). 


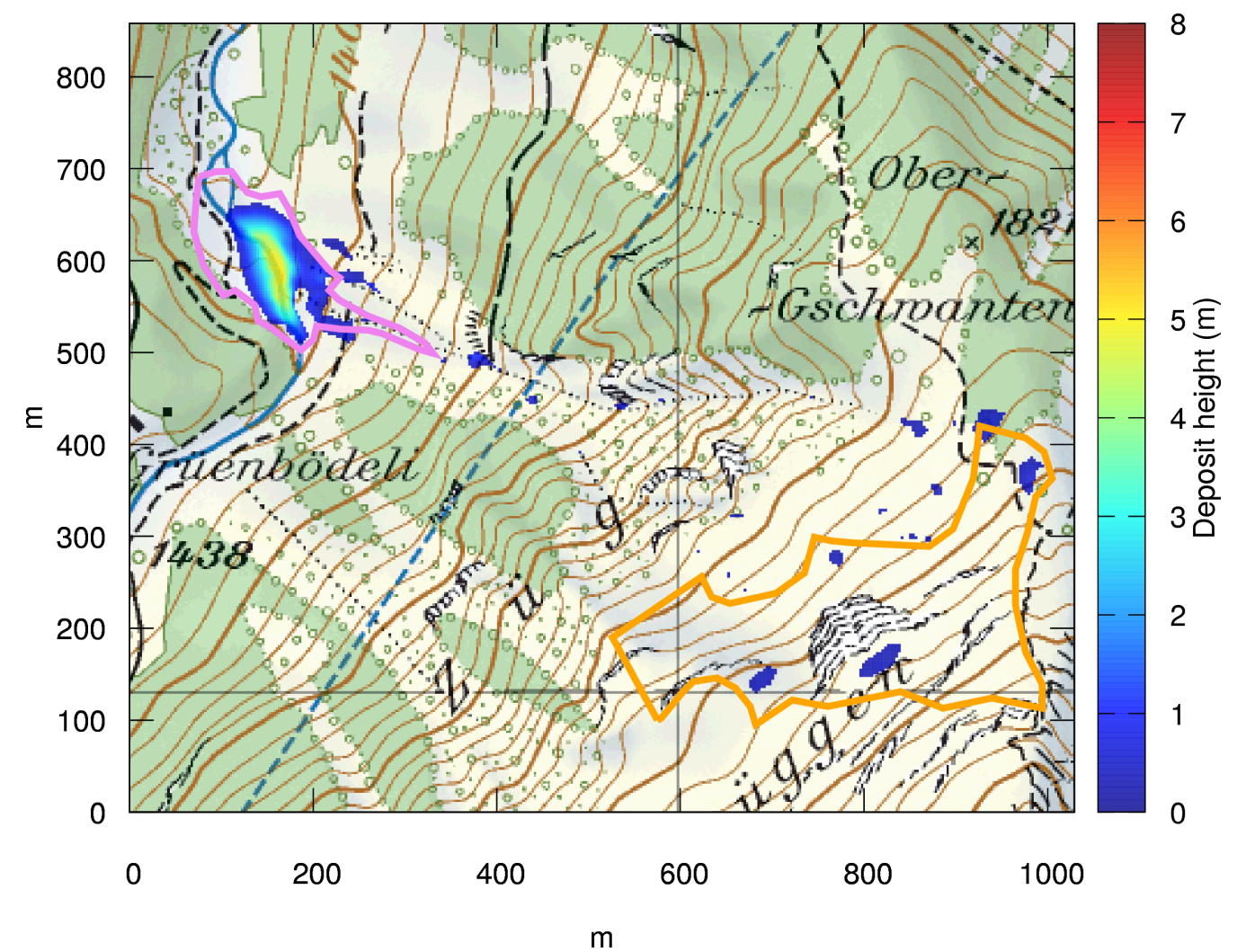

(a) Thermomechanical model RAMMS

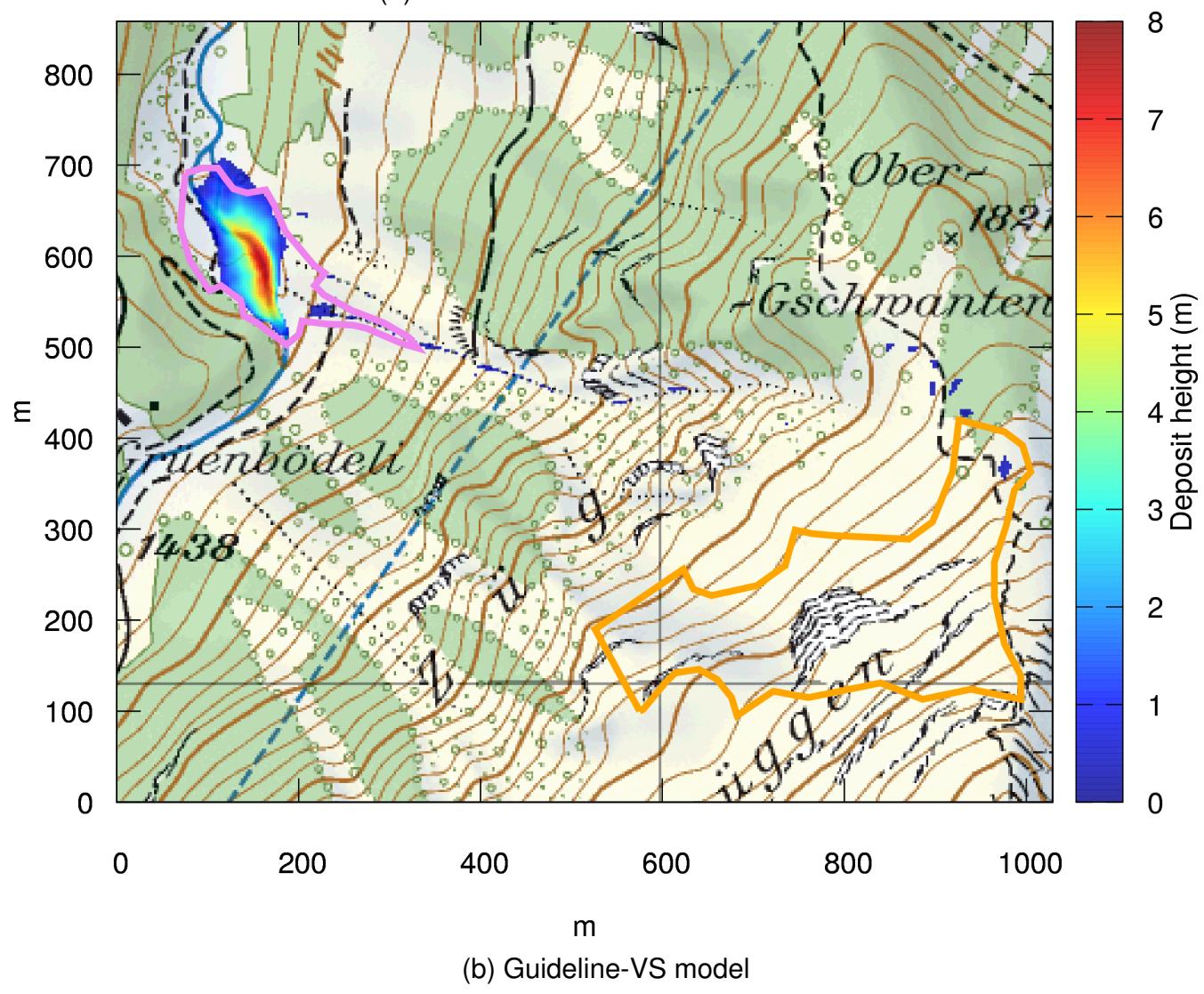

Figure S1: Gruenbodeli Davos. For description see page 2. 


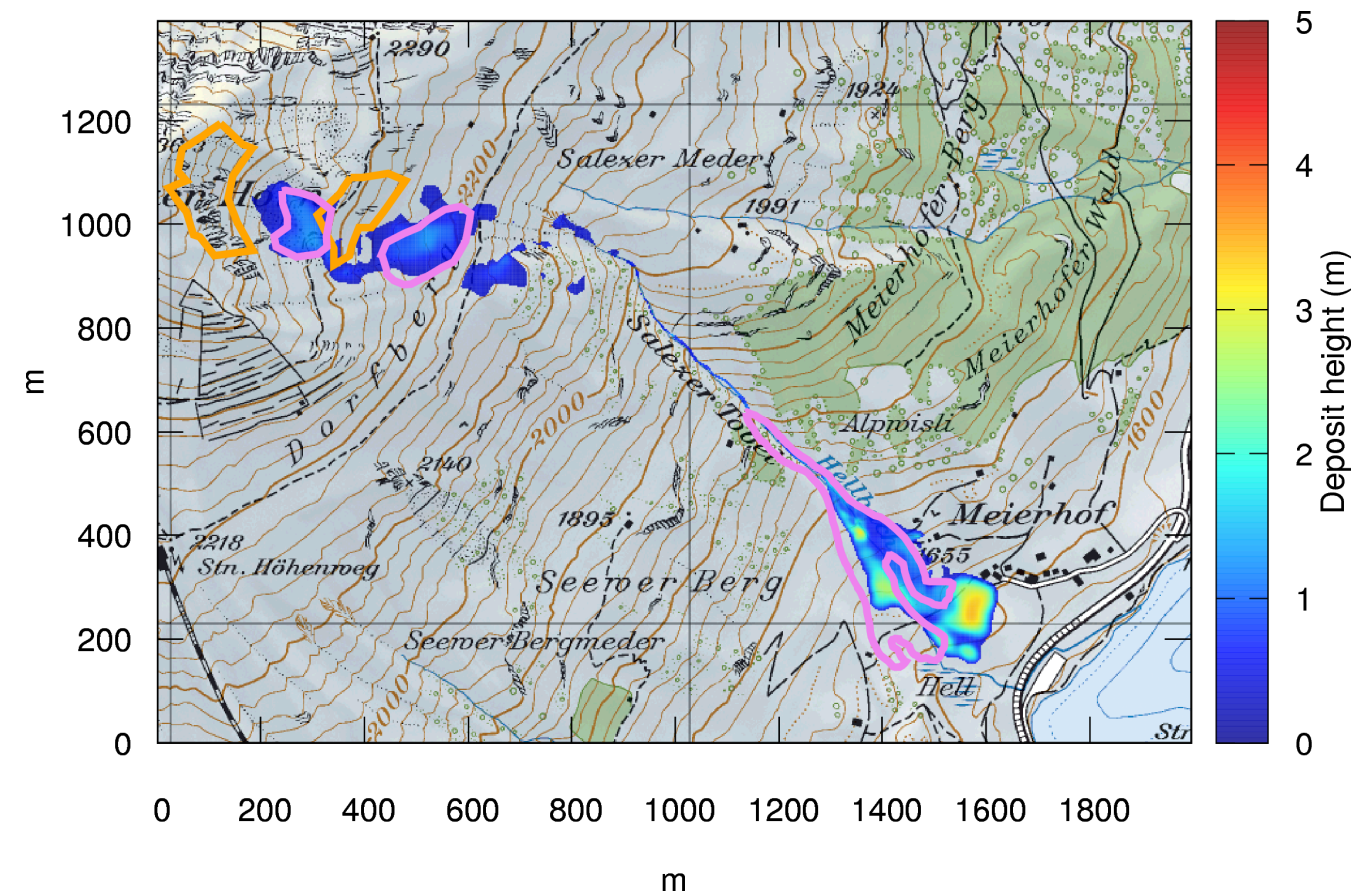

(a) Thermomechanical model RAMMS

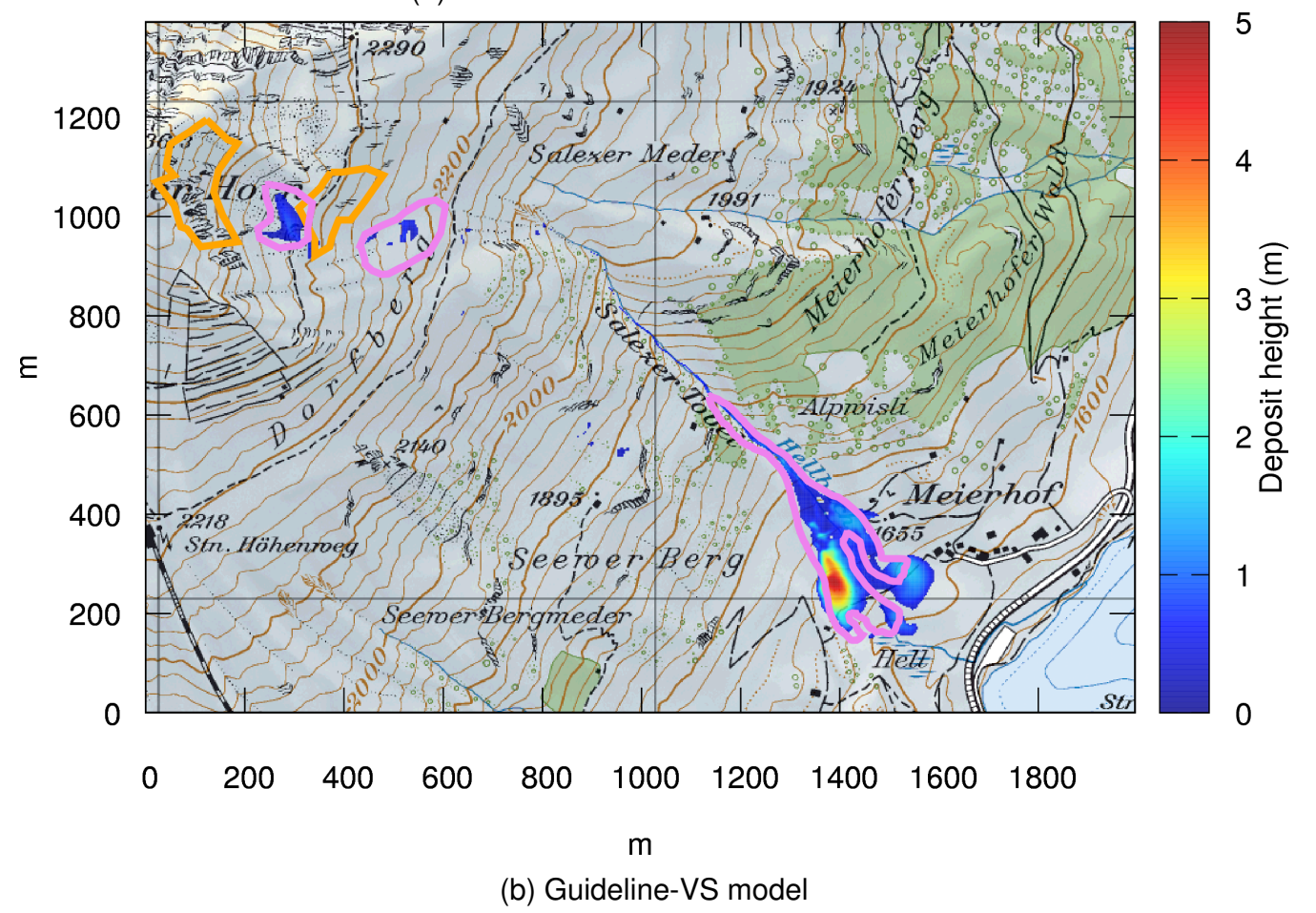

Figure S2: Salezer Davos. For description see page 2. 


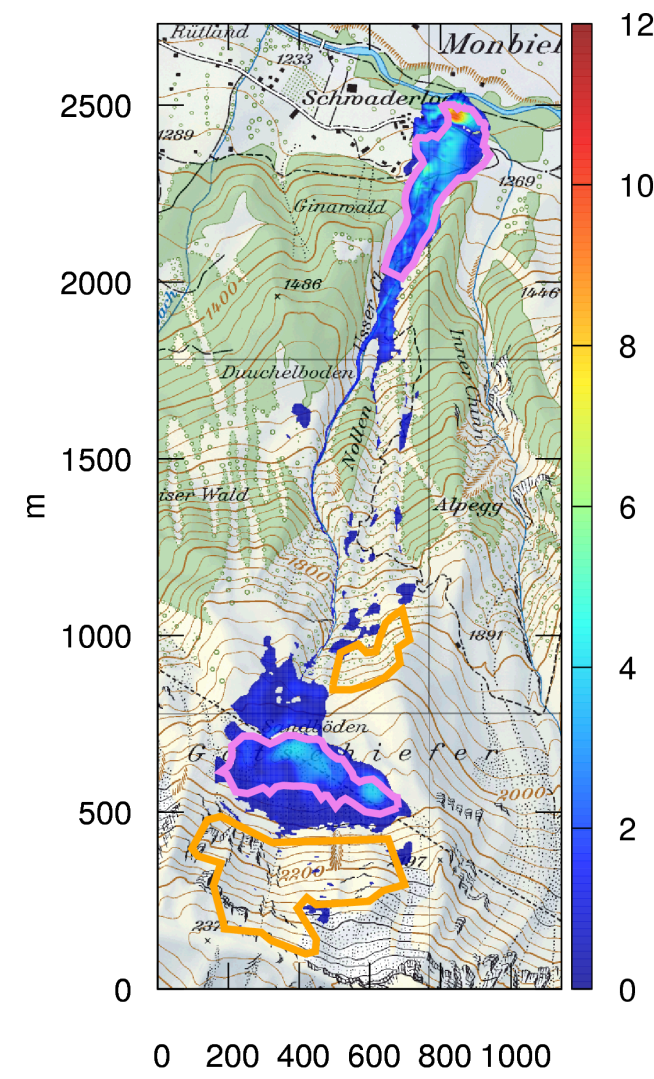

$\mathrm{m}$

(a) Thermomechanical model RAMMS

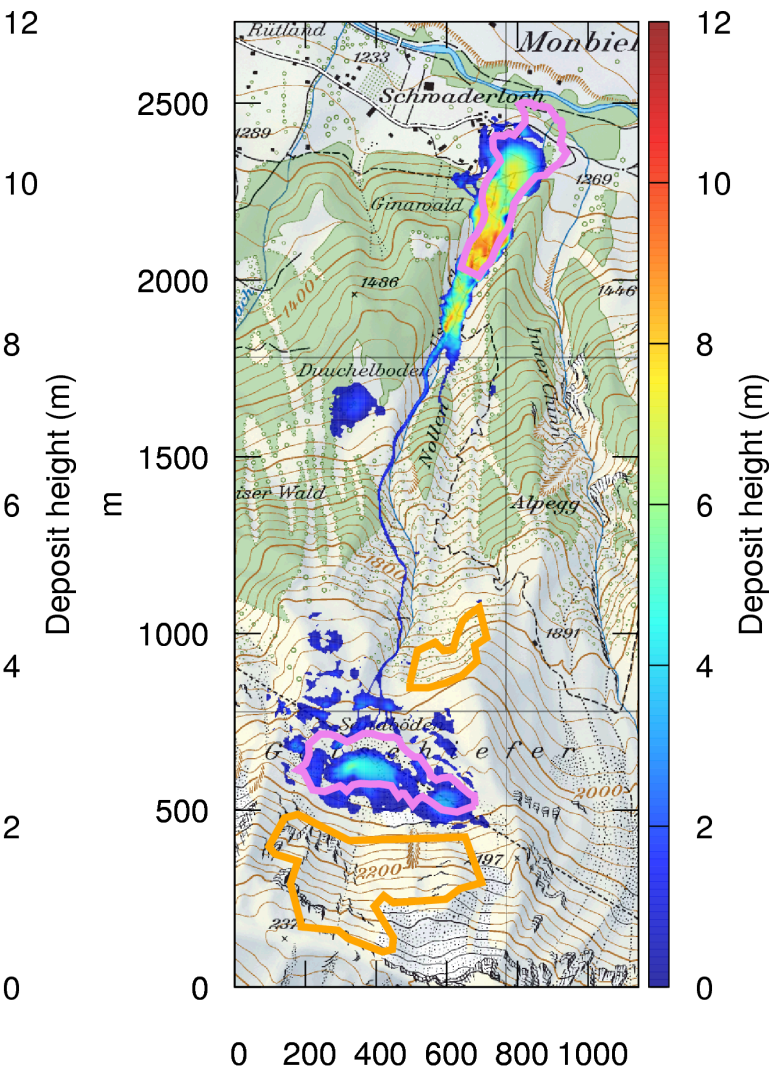

$\mathrm{m}$

Figure S3: Gatschiefer Davos. For description see page 2. 


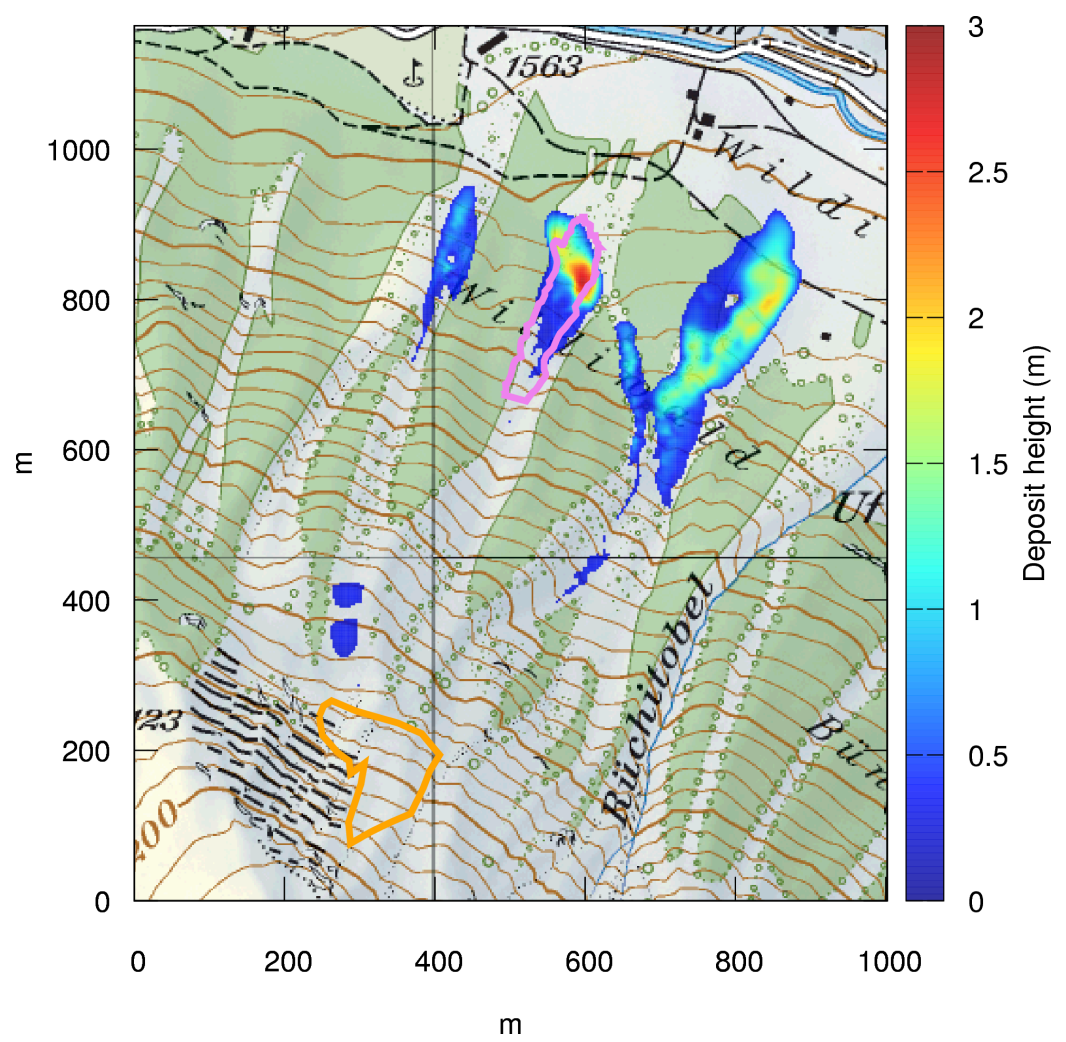

(a) Thermomechanical model RAMMS

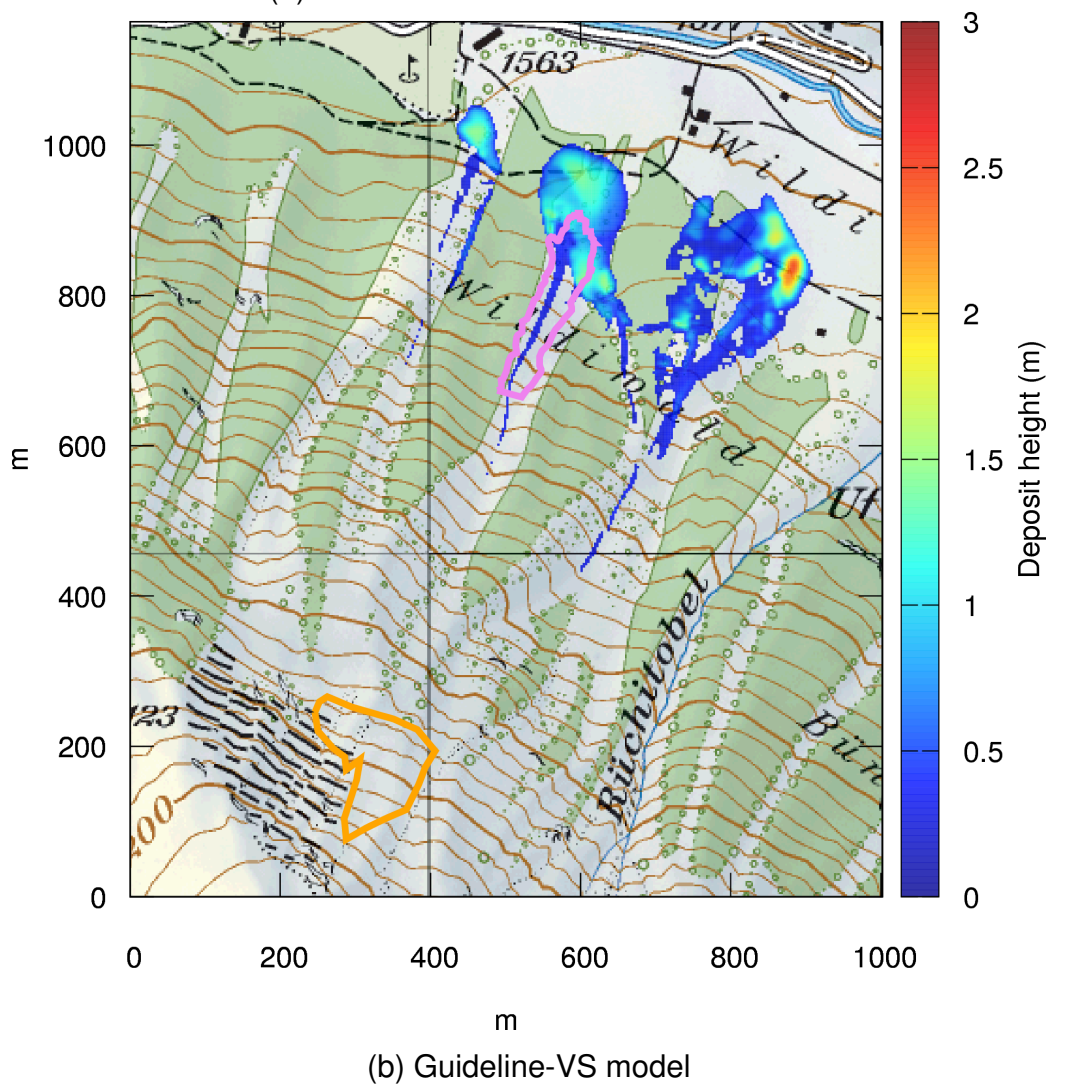

Figure S4: Braemabuhl 2013 Davos. For description see page 2. 


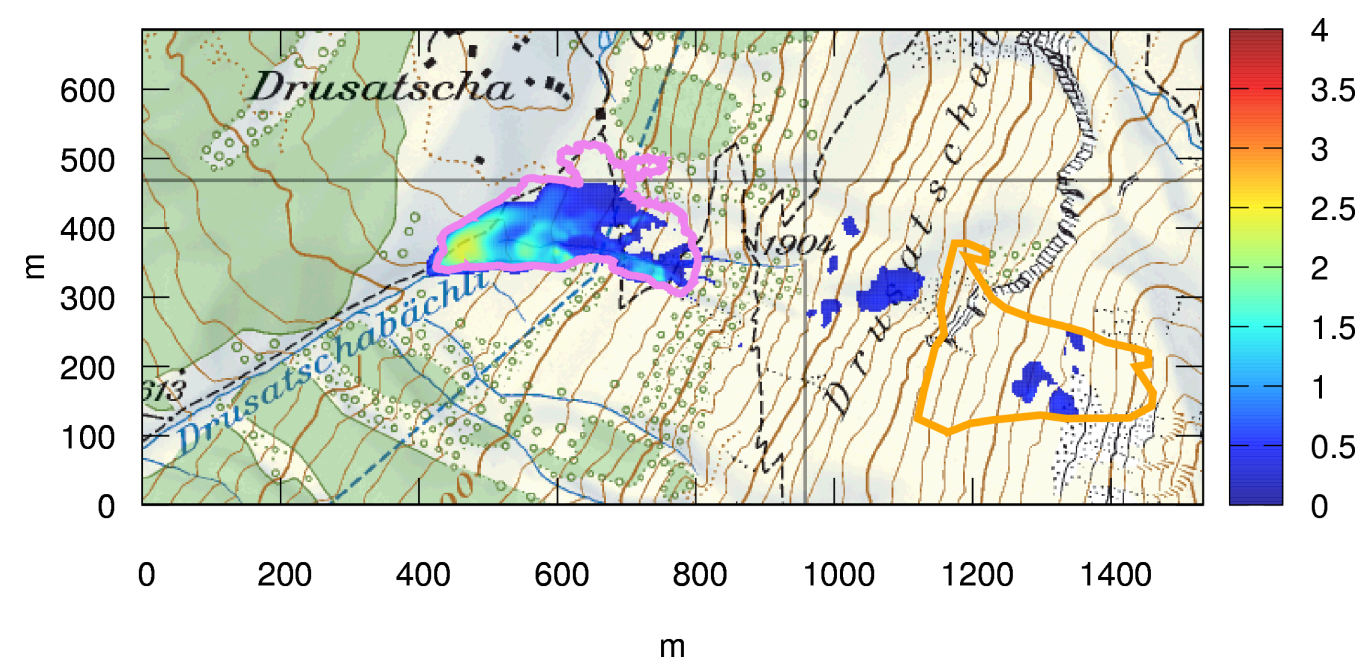

(a) Thermomechanical model RAMMS

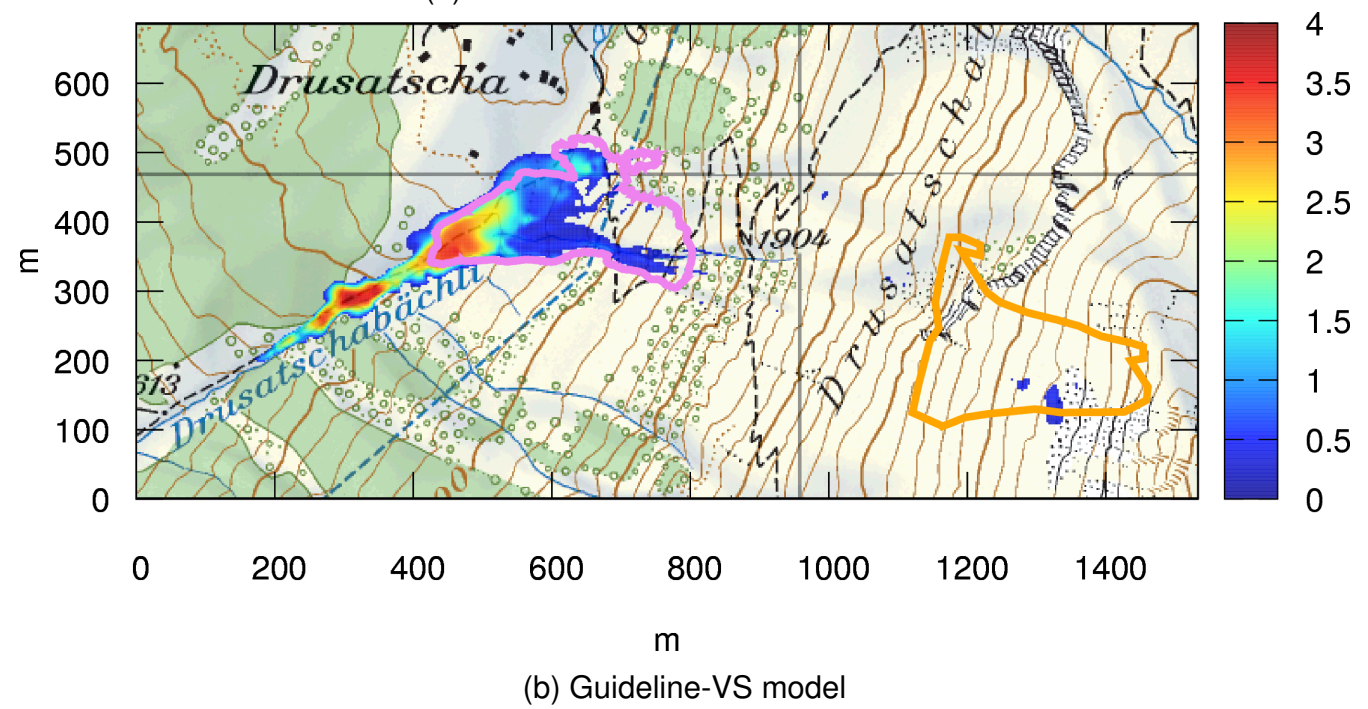

Figure S5: Drusatscha Davos. For description see page 2. 


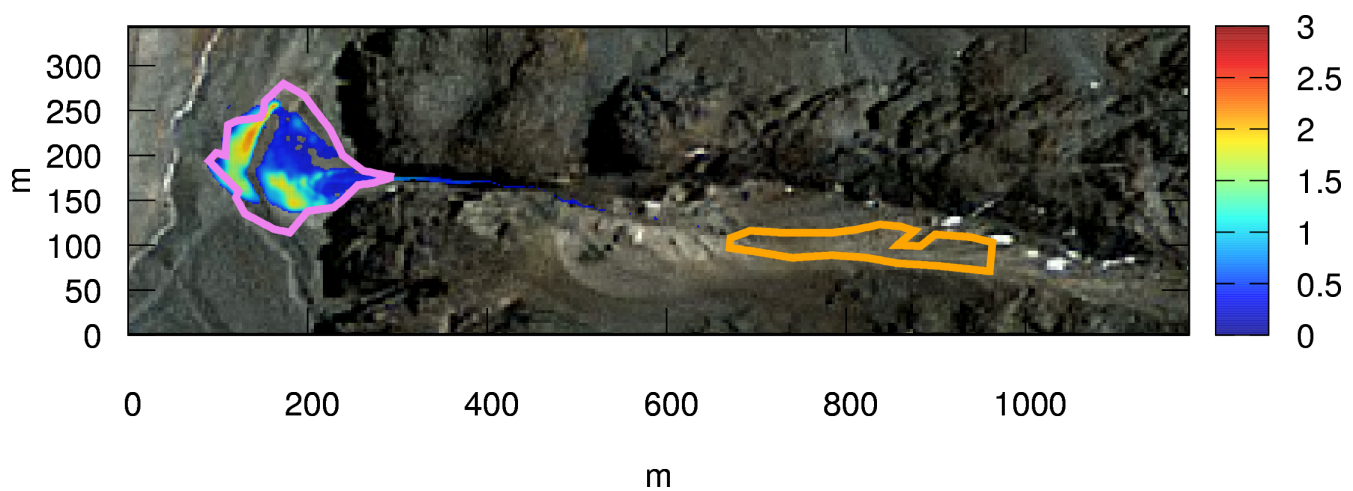

(a) Thermomechanical model RAMMS

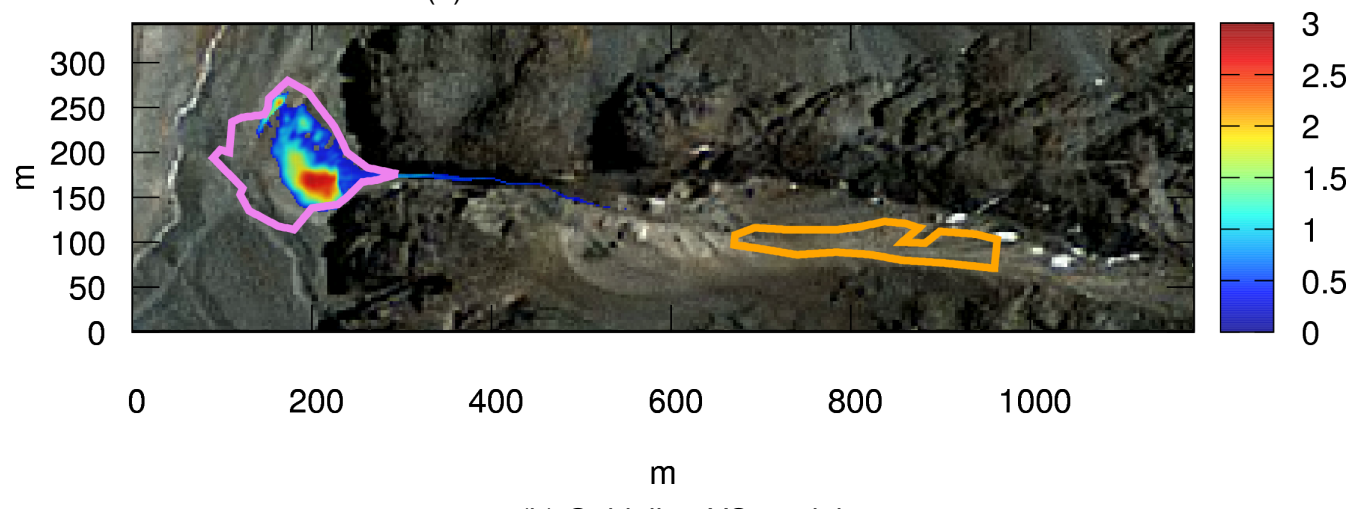

(b) Guideline-VS model

Figure S6: Codelco Andina MO-4. For description see page 2. 


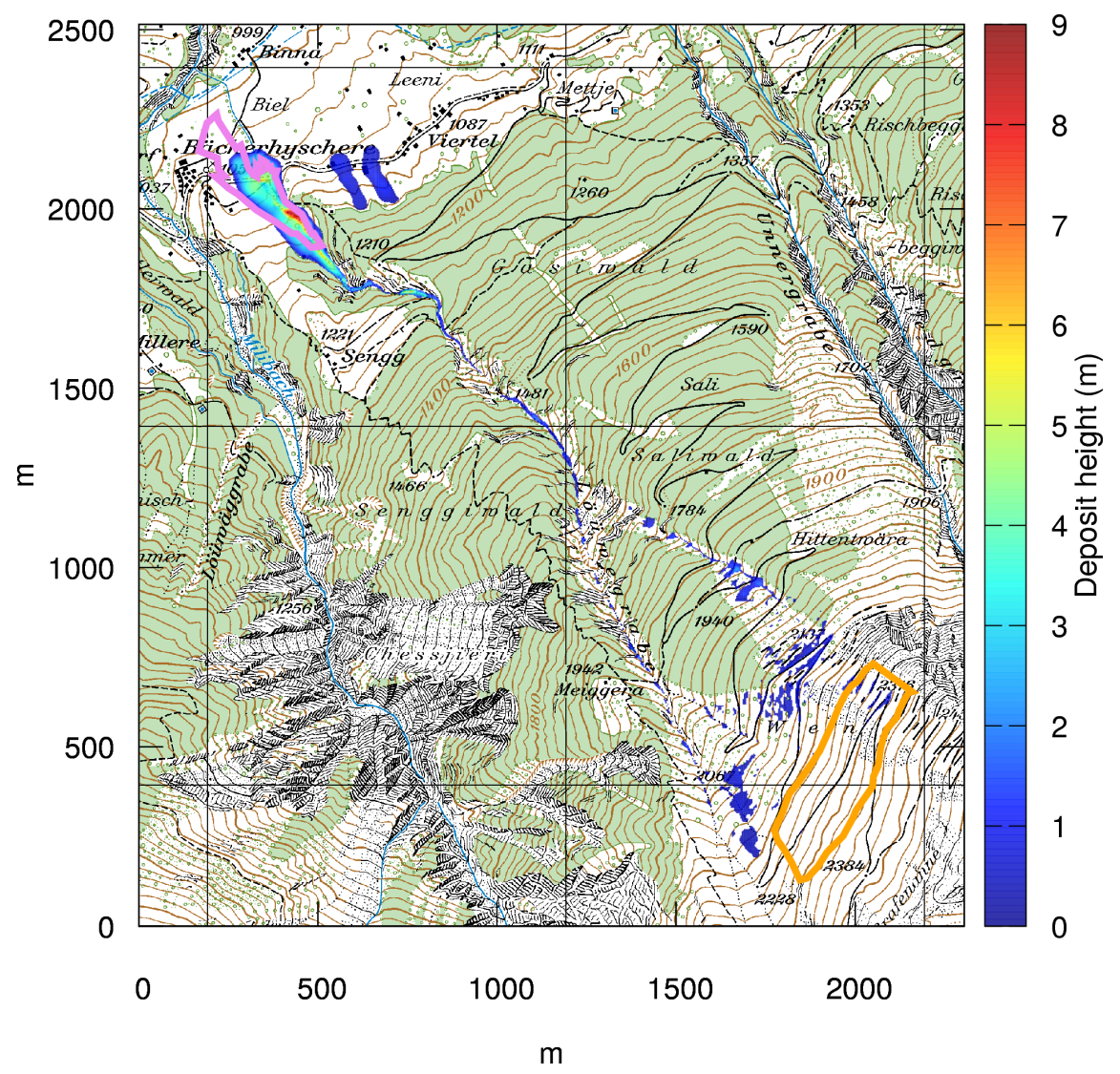

(a) Thermomechanical model RAMMS

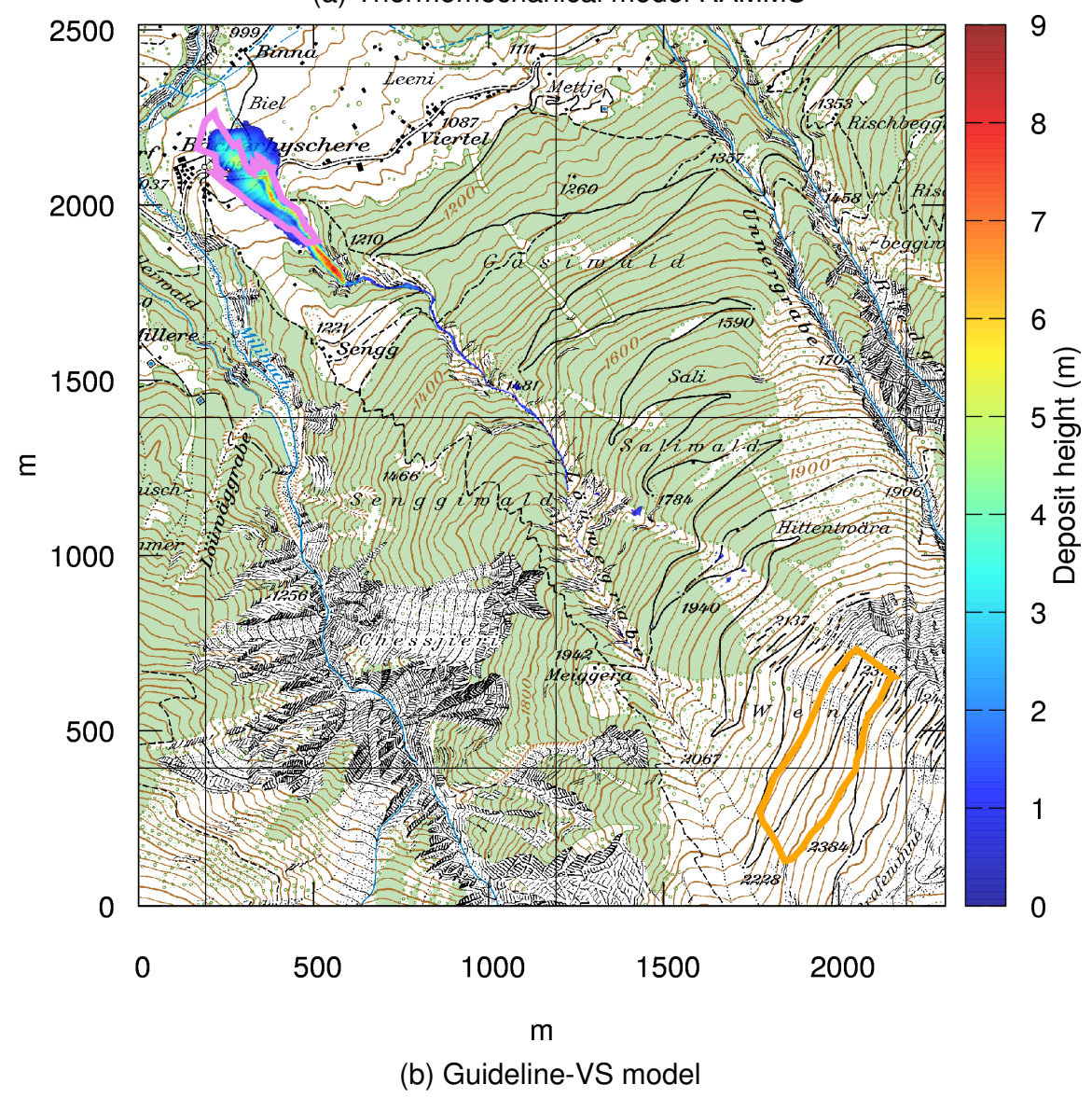

Figure S7: Grengiols. For description see page 2. 


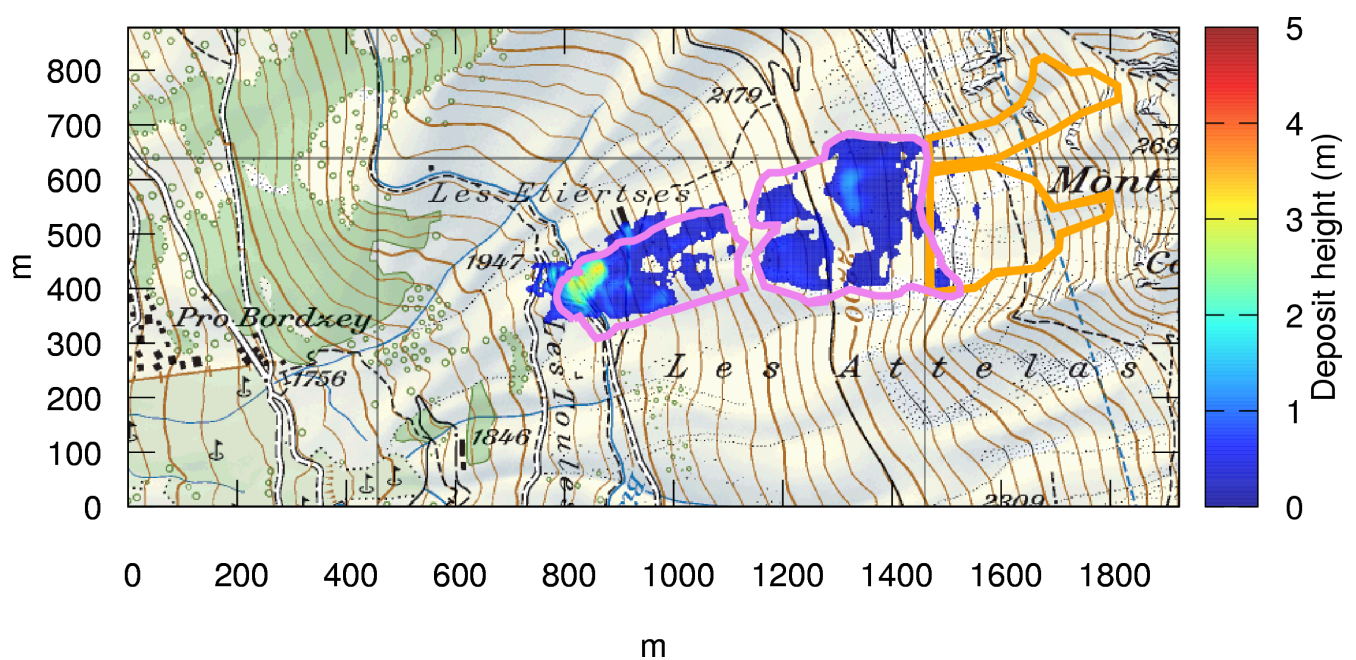

(a) Thermomechanical model RAMMS

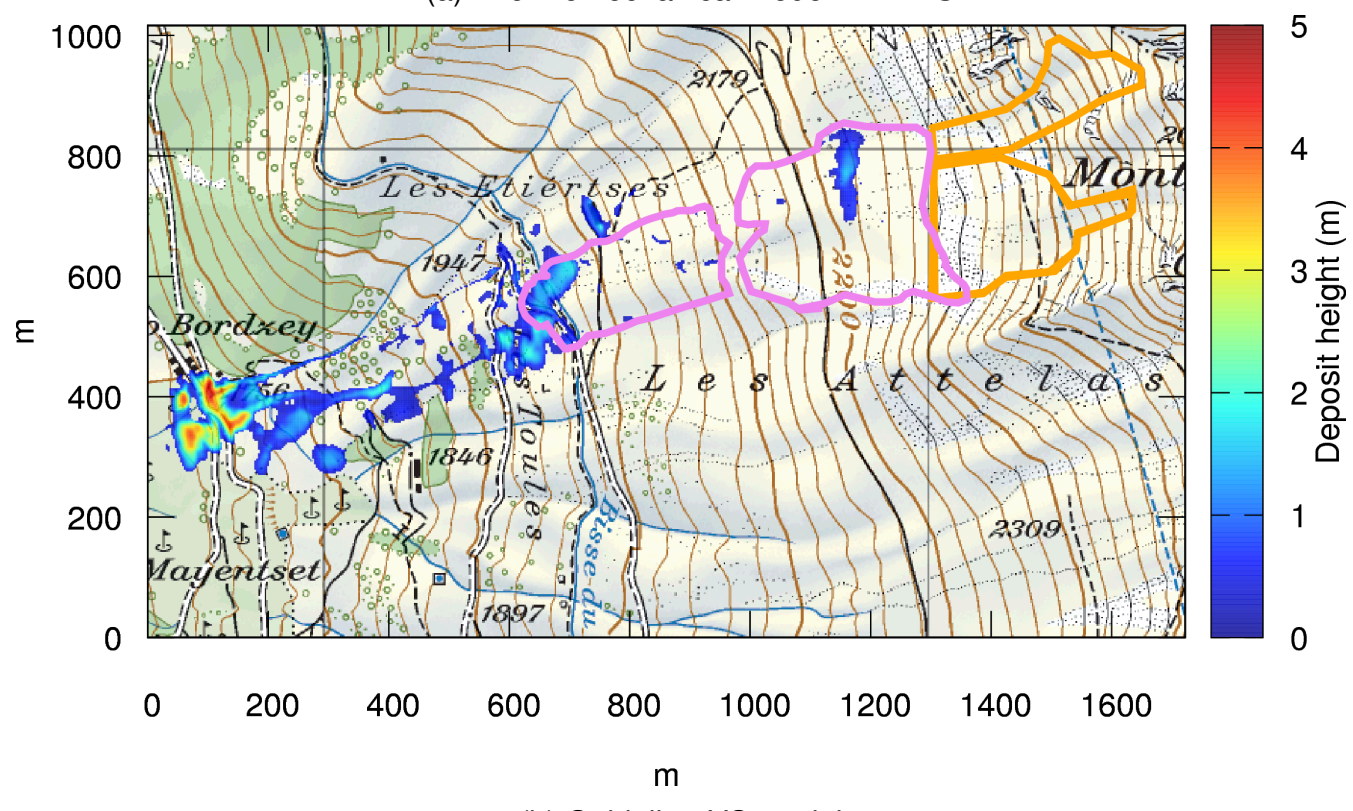

(b) Guideline-VS model

Figure S8: Mont Rogneux Verbier. For description see page 2. 


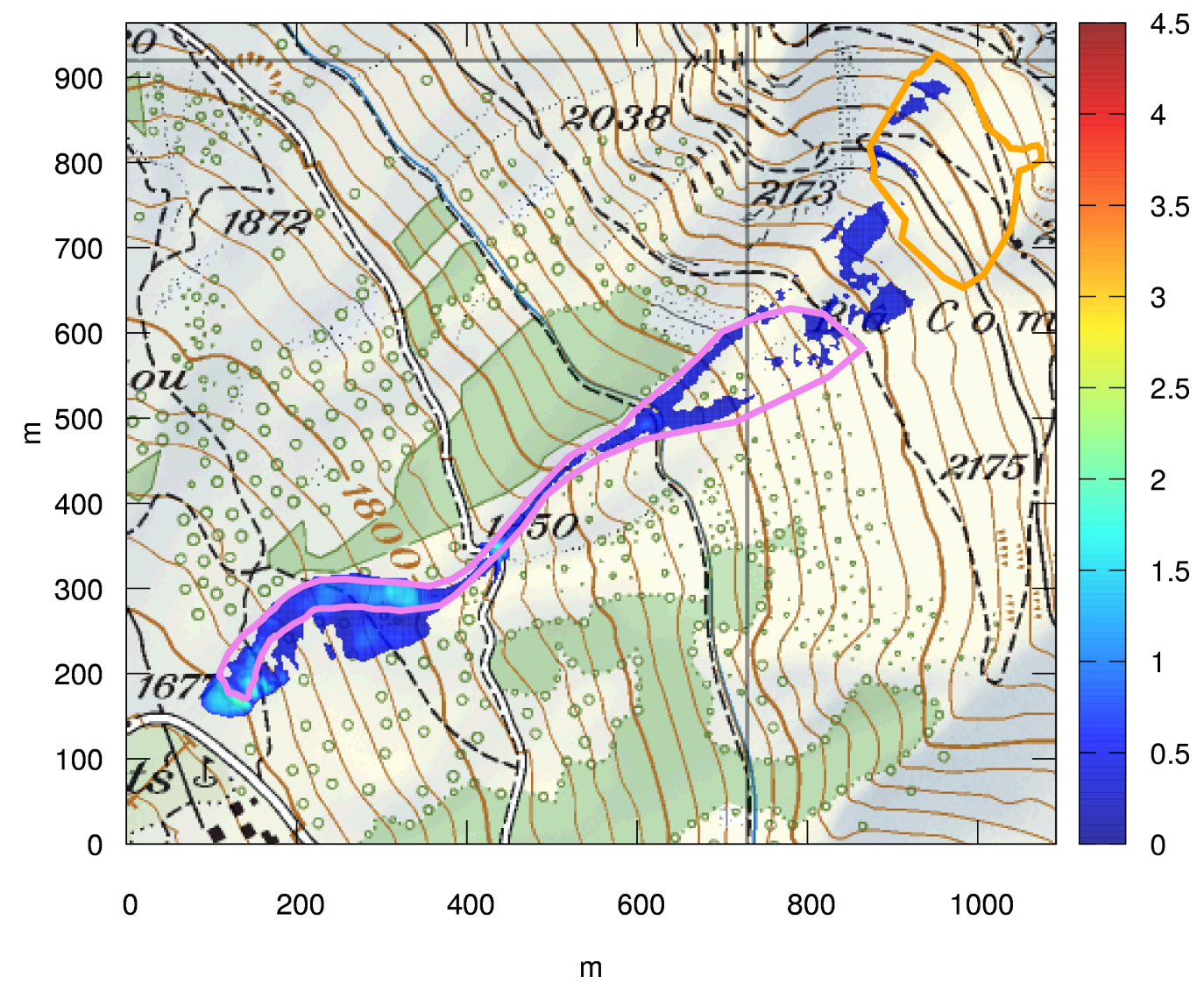

(a) Thermomechanical model RAMMS

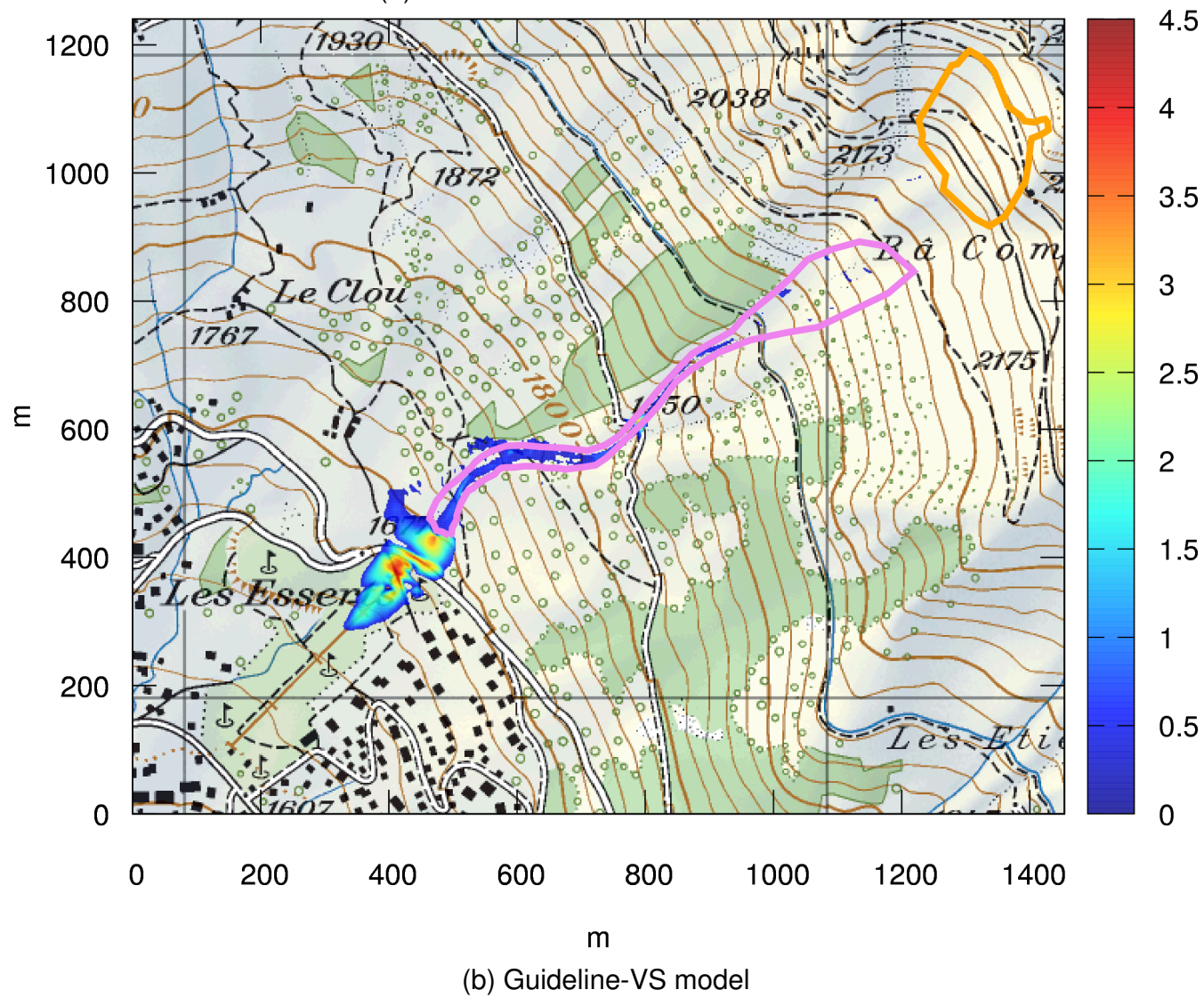

Figure S9: Ba Combe Verbier. For description see page 2. 


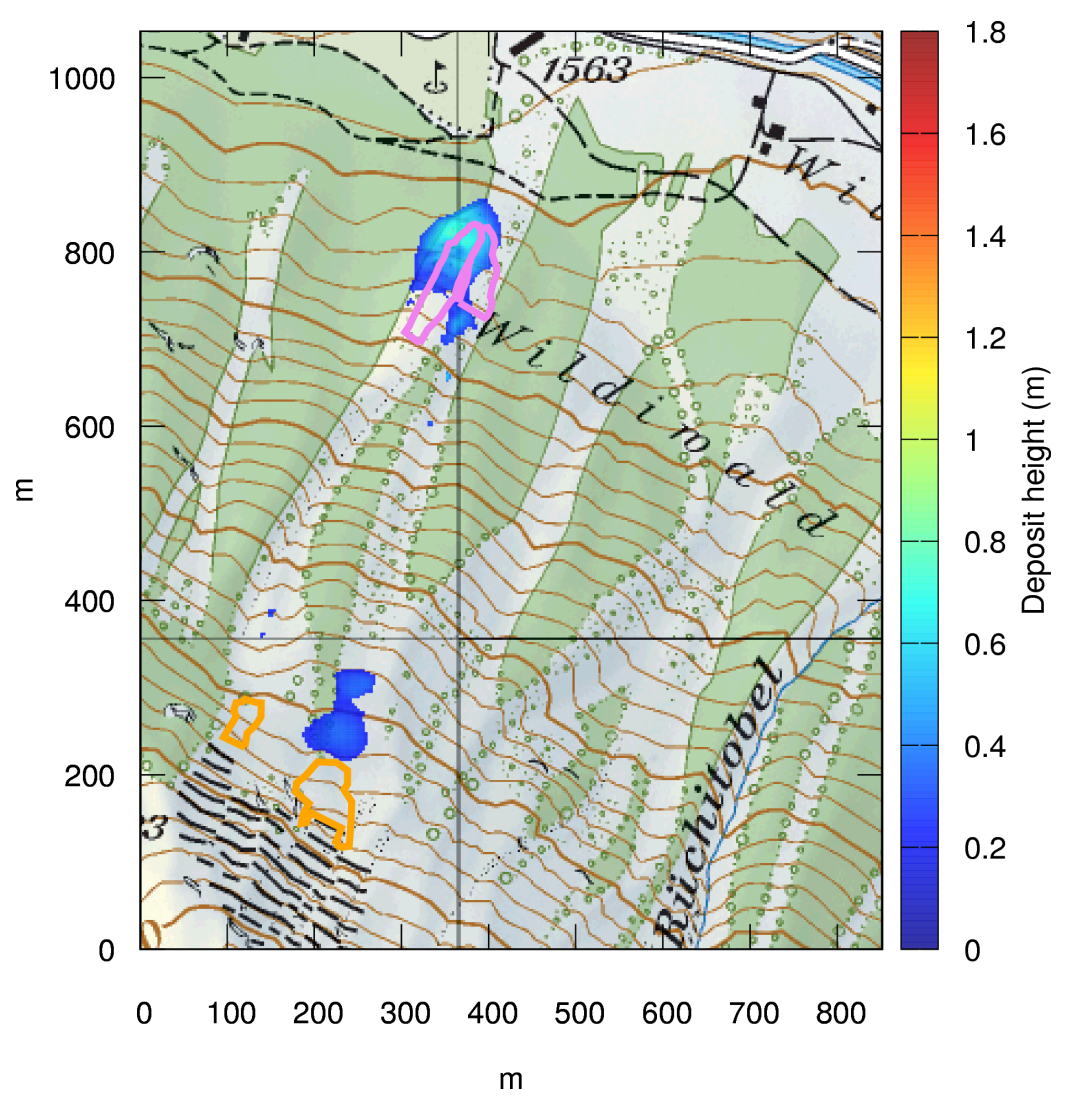

(a) Thermomechanical model RAMMS

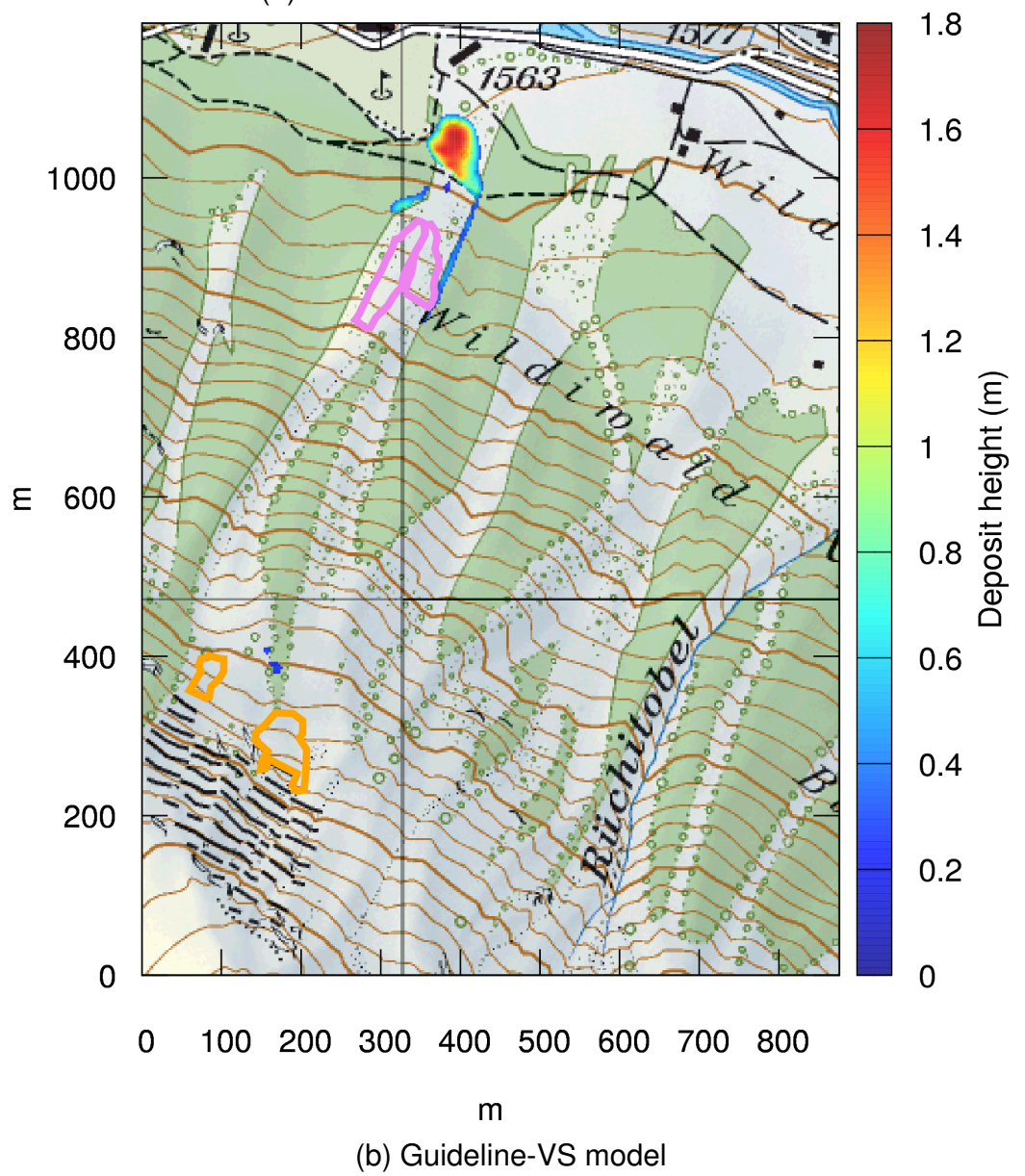

Figure S10: Braemabuhl Verbauung Davos. For description see page 2. 


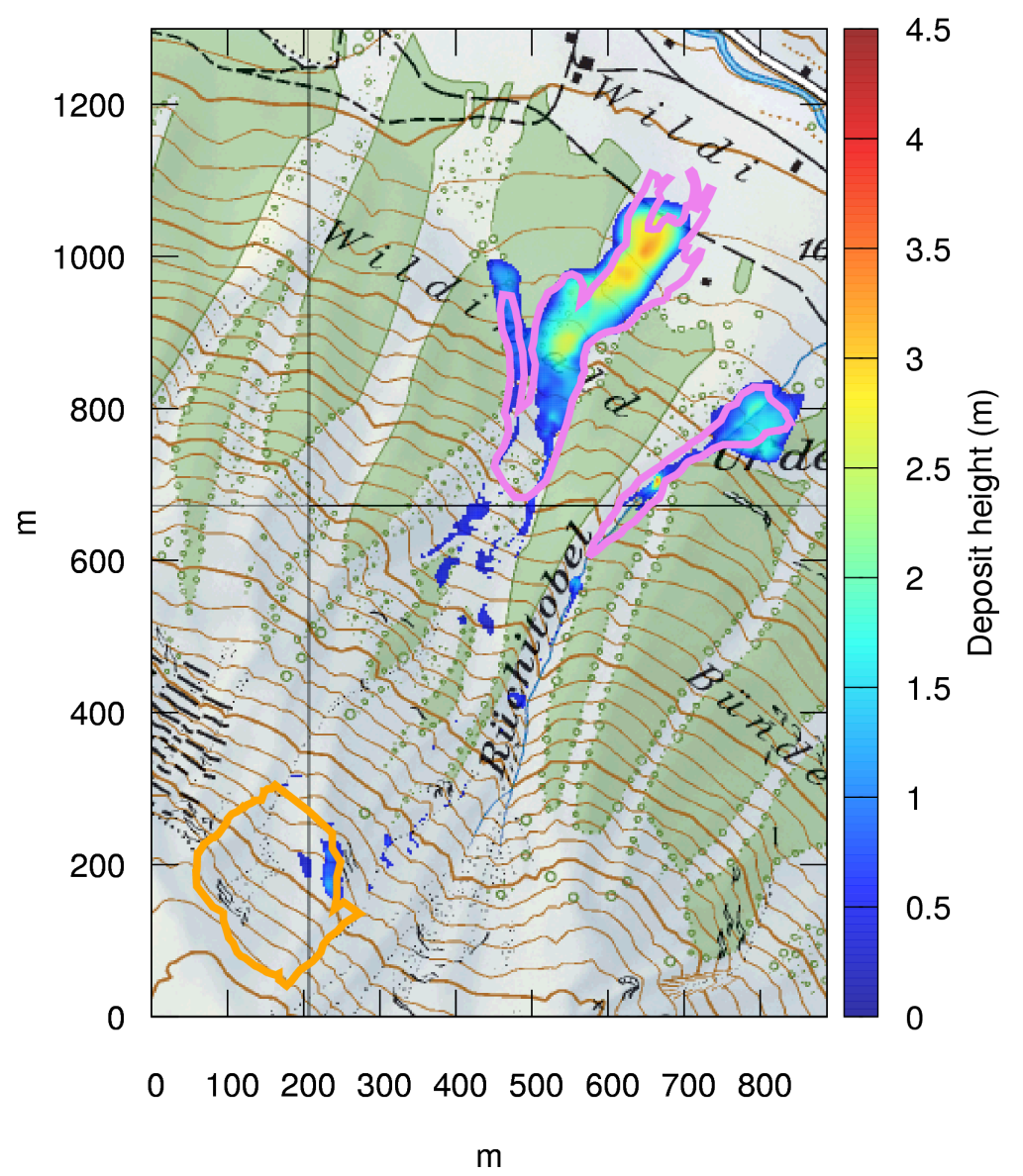

(a) Thermomechanical model RAMMS

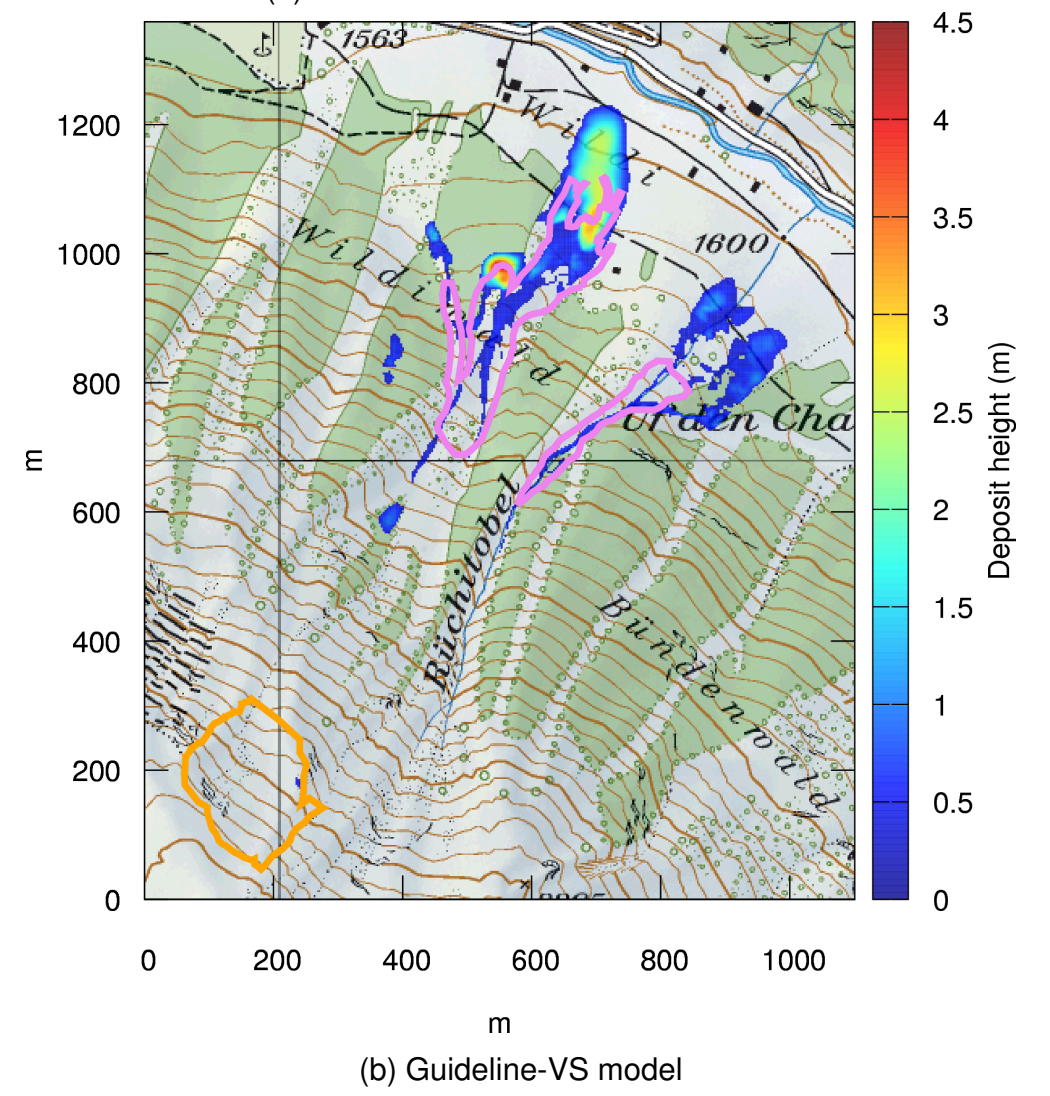

Figure S11: Wildi Davos. For description see page 2. 


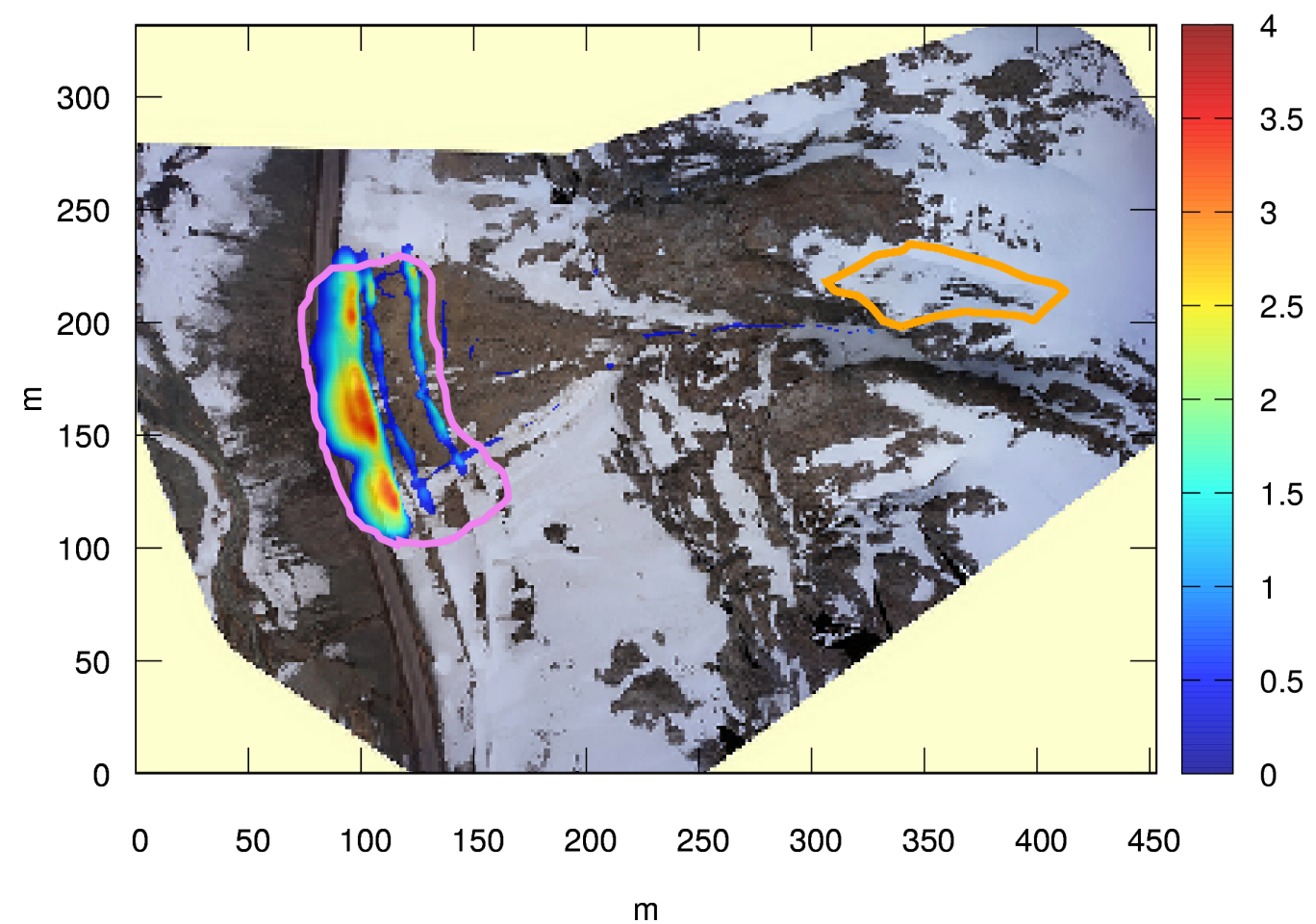

(a) Thermomechanical model RAMMS

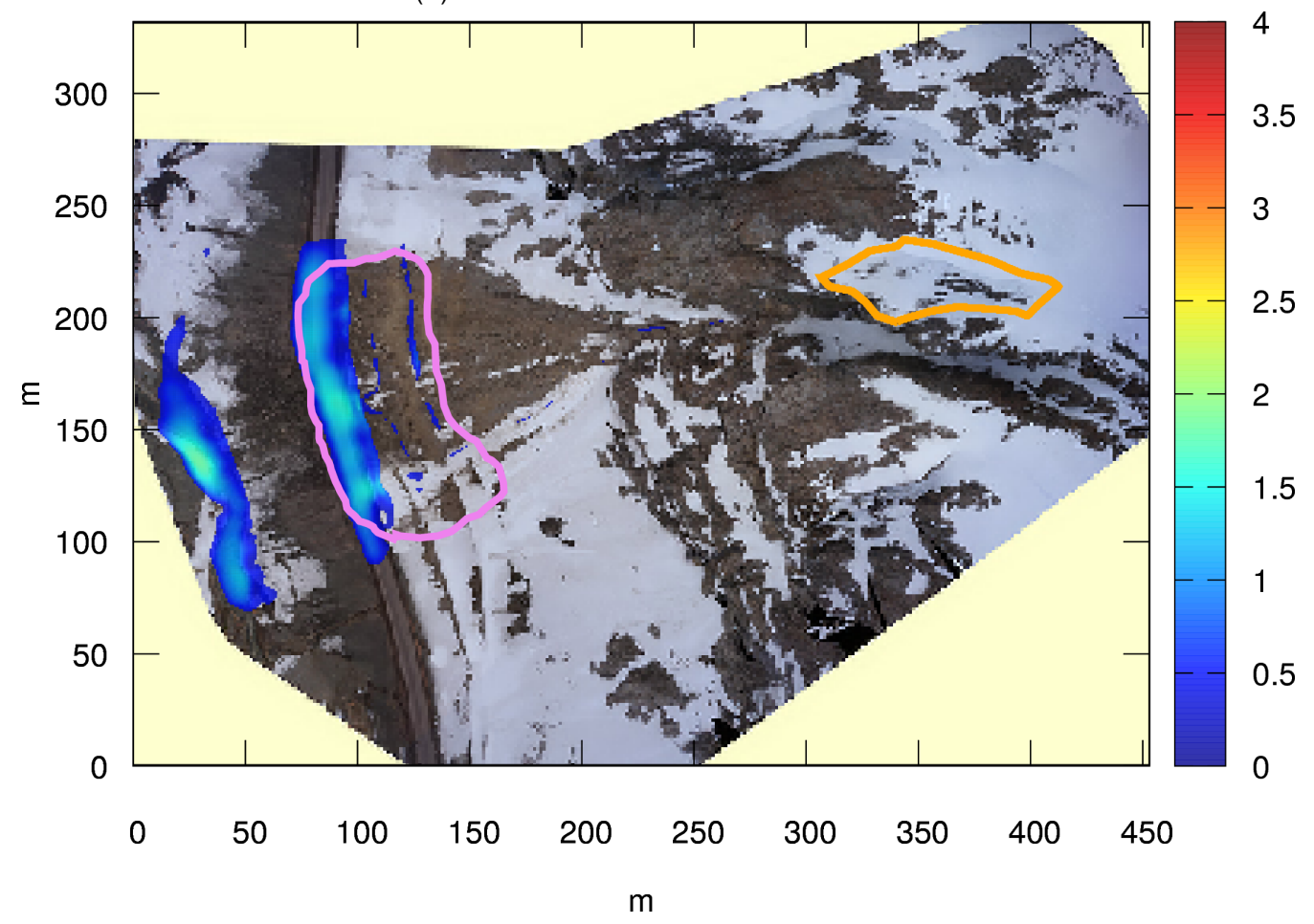

(b) Guideline-VS model

Figure S12: Codelco Andina CV-1. For description see page 2. 


\section{Supplement B}

The following pages show the runout sensitivity analysis calculations performed with the thermomechanical model RAMMS for the 12 case studies. The upper or left plot in each figure correspond to the 12 simulations performed interchanging all the initial and boundary conditions: fracture and erosion depth, density, snow temperature and liquid water content for the 12 case studies. The middle plot corresponds to simulations where the initial mass conditions were interchanged: fracture and erosion depth plus density are interchange among the 12 case studies. The lower or right plot corresponds to simulations where the initial snowcover conditions were interchanged: snowcover temperature and liquid water content for the 12 case studies. For each figure the measured released and deposits areas are shown in an orange and green polygon, respectively. The color bar denotes deposits height (i.e., flow height in last time step $>20 \mathrm{~cm}$ ) of the simulation with the initial conditions corresponding to the event. The outlines of the simulated deposits (i.e., flow height in last time step $>20 \mathrm{~cm}$ ) for each of the other 11 different initial conditions are shown in varying degrees of rosa to red color. 

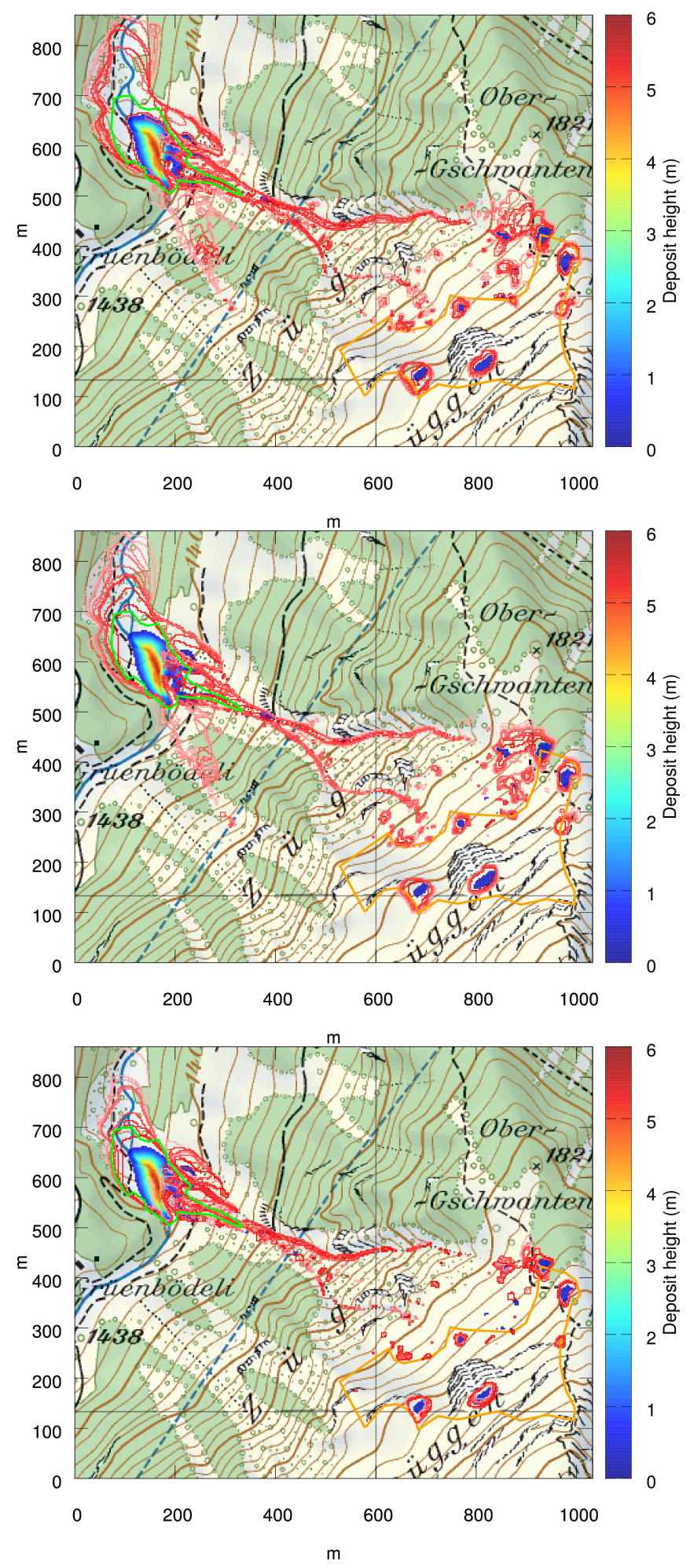

Figure S13: Gruenbodeli Davos. For description see page 15. 

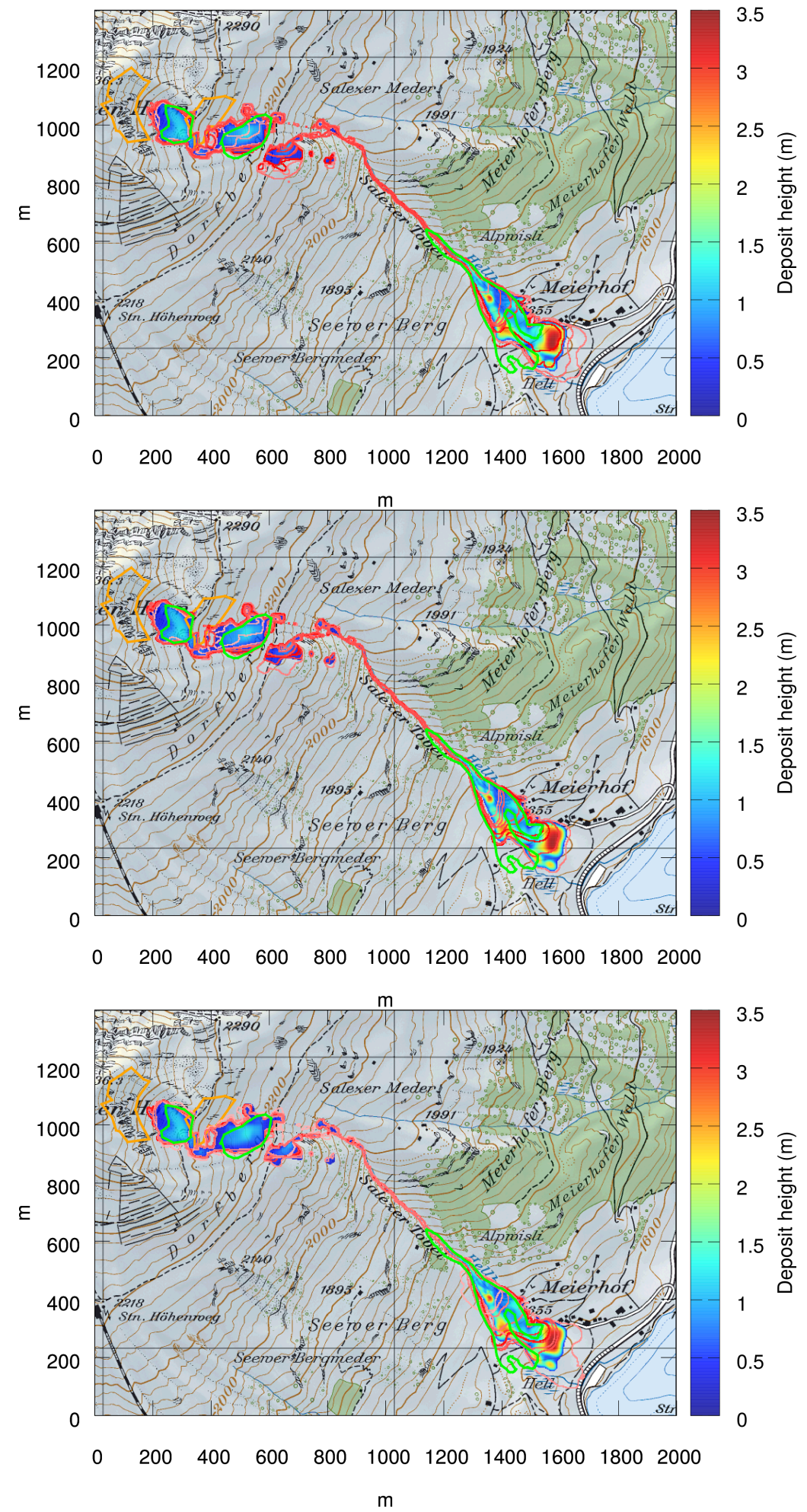

Figure S14: Salezer Davos. For description see page 15. 


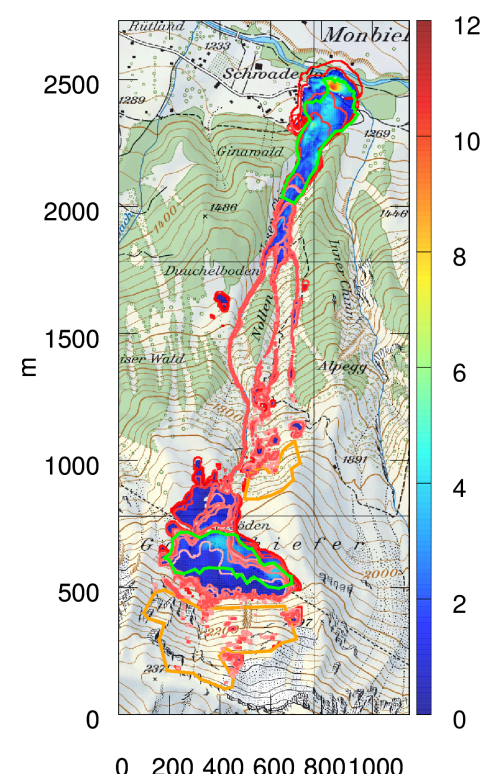

$\mathrm{m}$

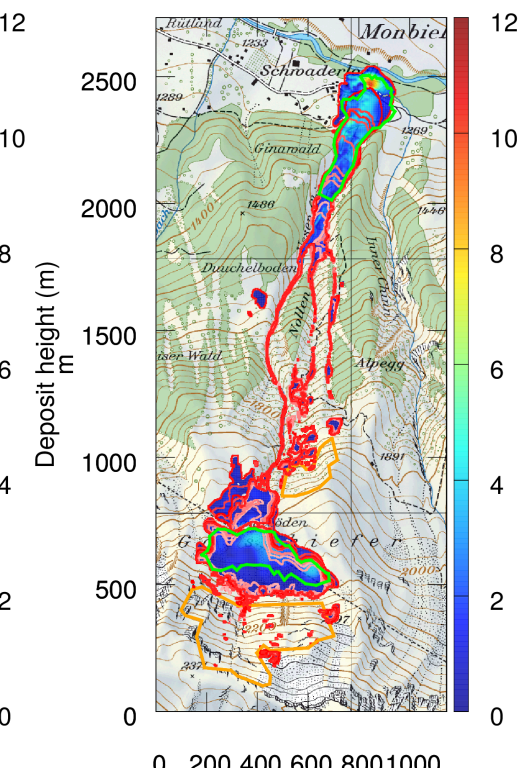

02004006008001000

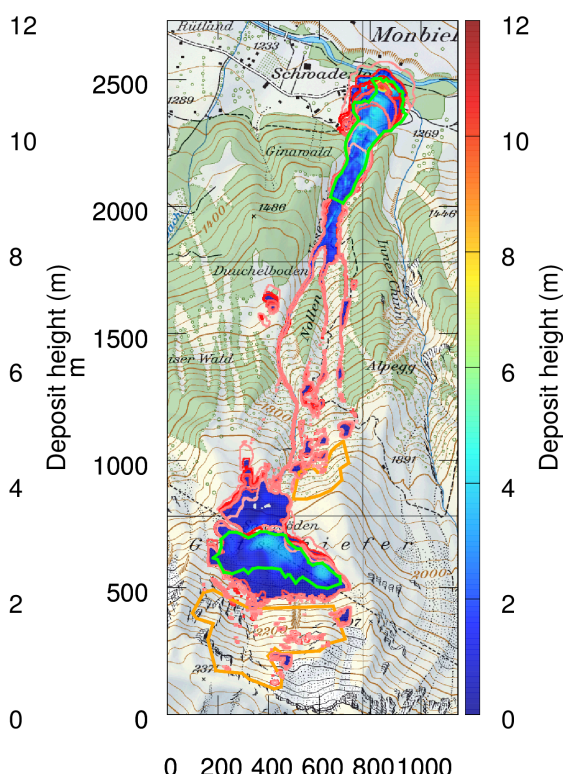

02004006008001000

Figure S15: Gatschiefer Davos. For description see page 15. 

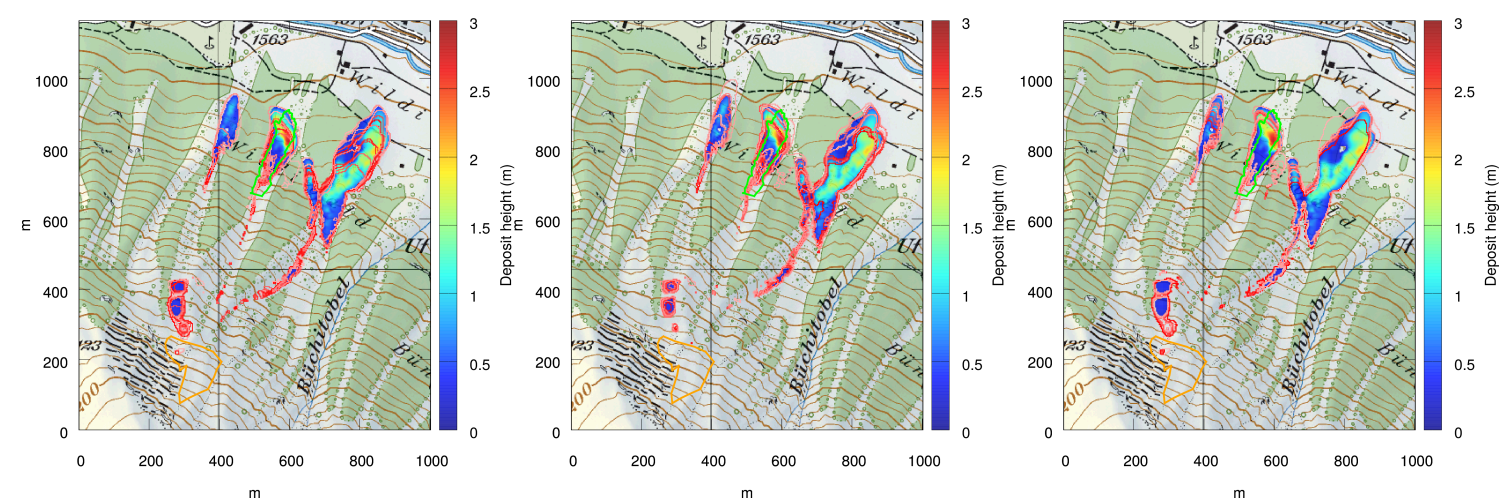

Figure S16: Braemabuhl 2013 Davos. For description see page 15. 

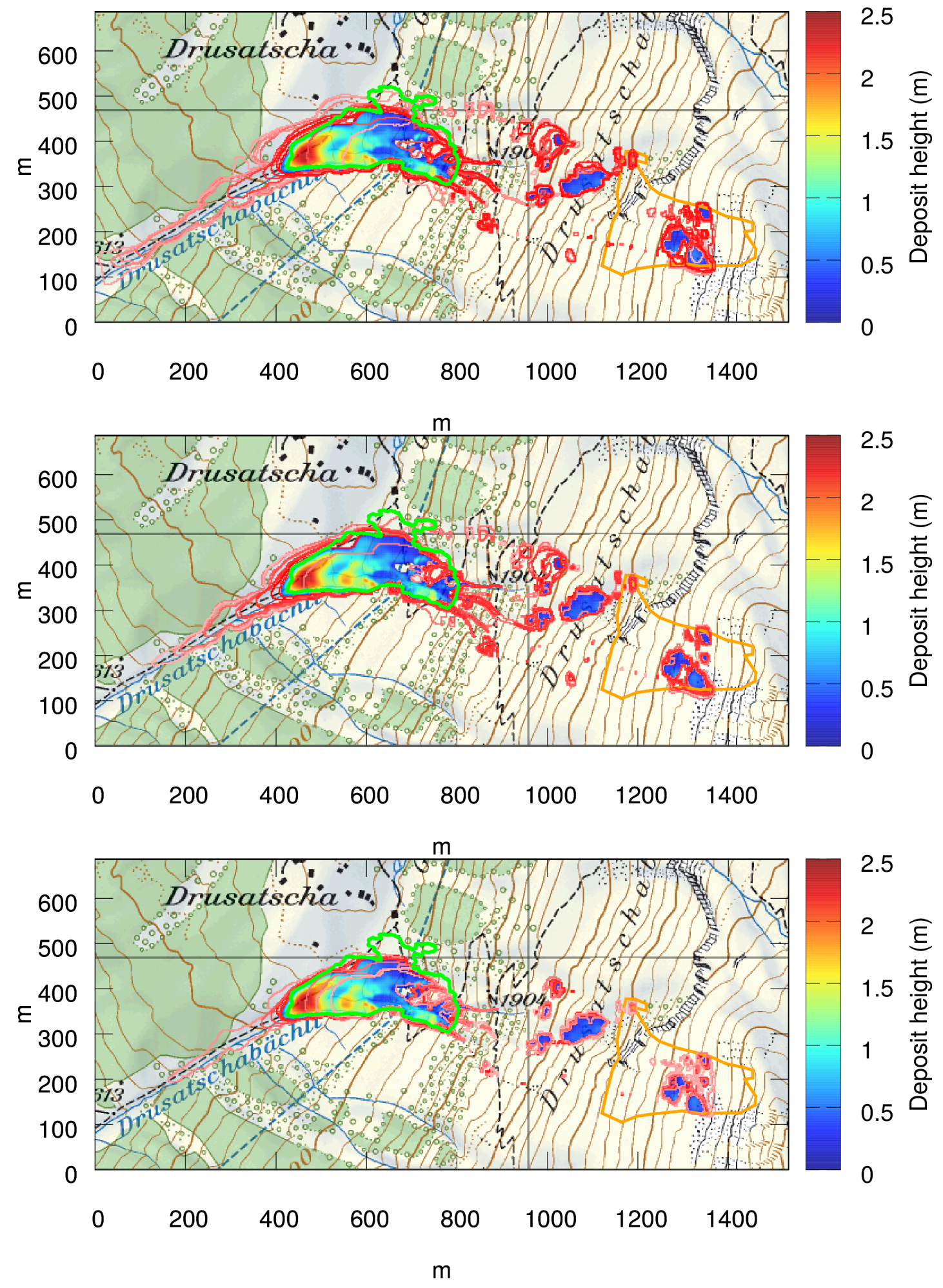

Figure S17: Drusatscha Davos. For description see page 15. 

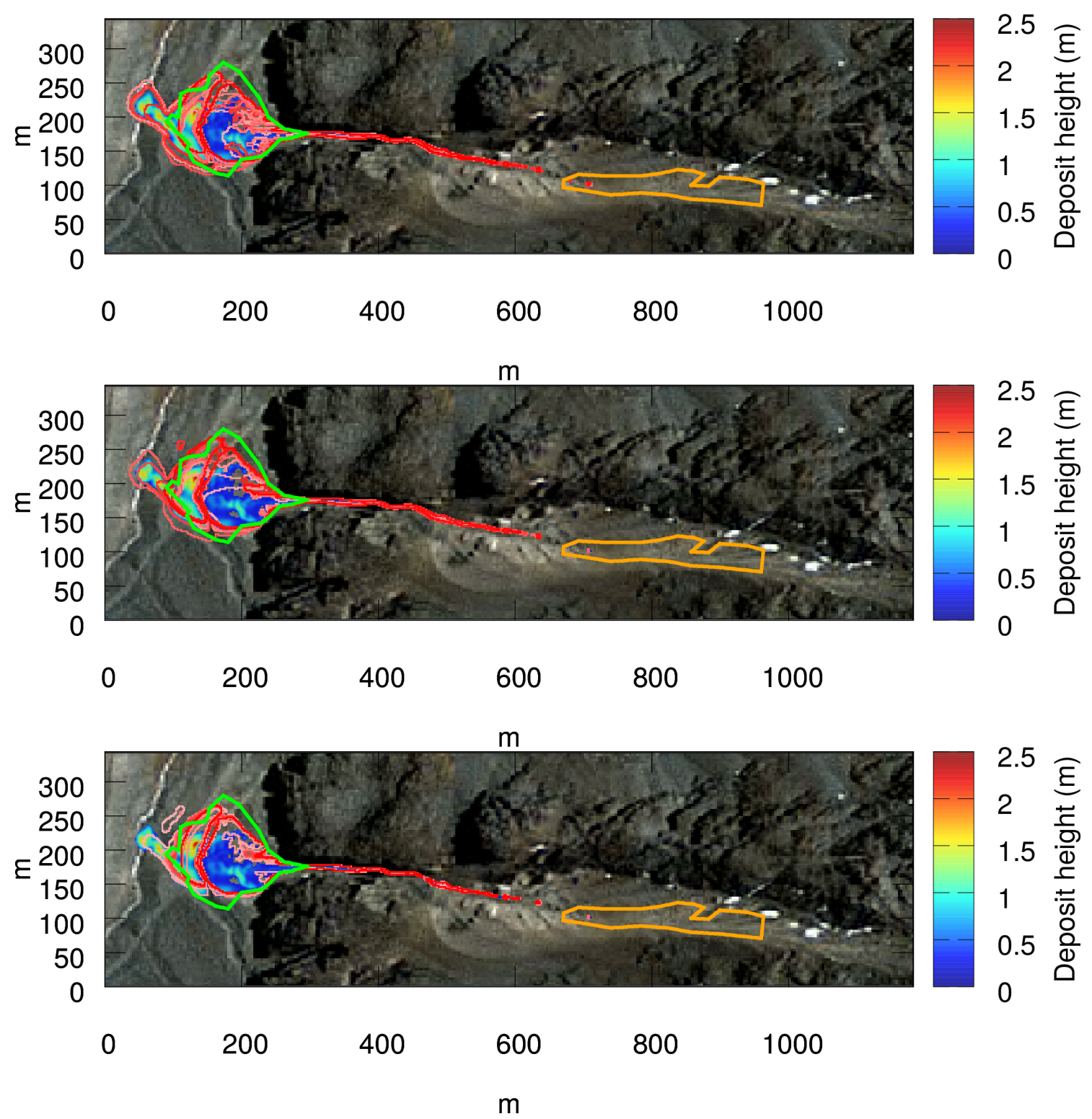

Figure S18: Codelco Andina Chile MO-4. For description see page 15. 



Figure S19: Grengiols. For description see page 15. 


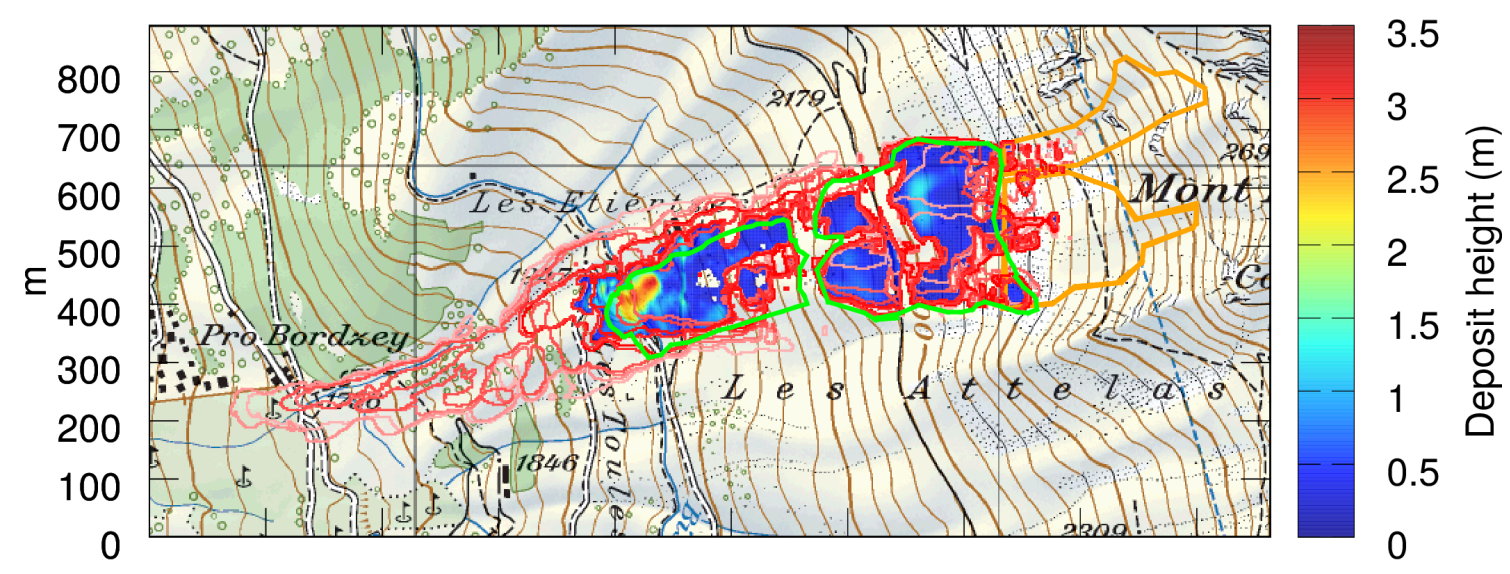

$\begin{array}{llllllllll}0 & 200 & 400 & 600 & 800 & 1000 & 1200 & 1400 & 1600 & 1800\end{array}$

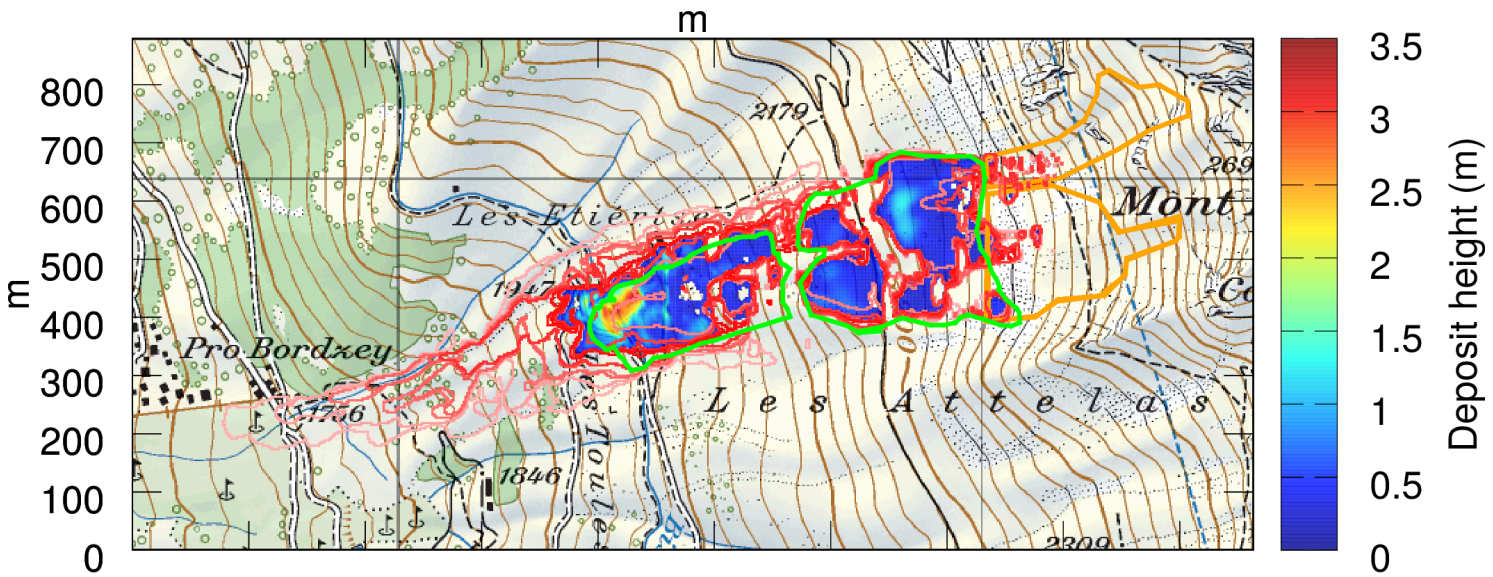

$\begin{array}{llllllllll}0 & 200 & 400 & 600 & 800 & 1000 & 1200 & 1400 & 1600 & 1800\end{array}$

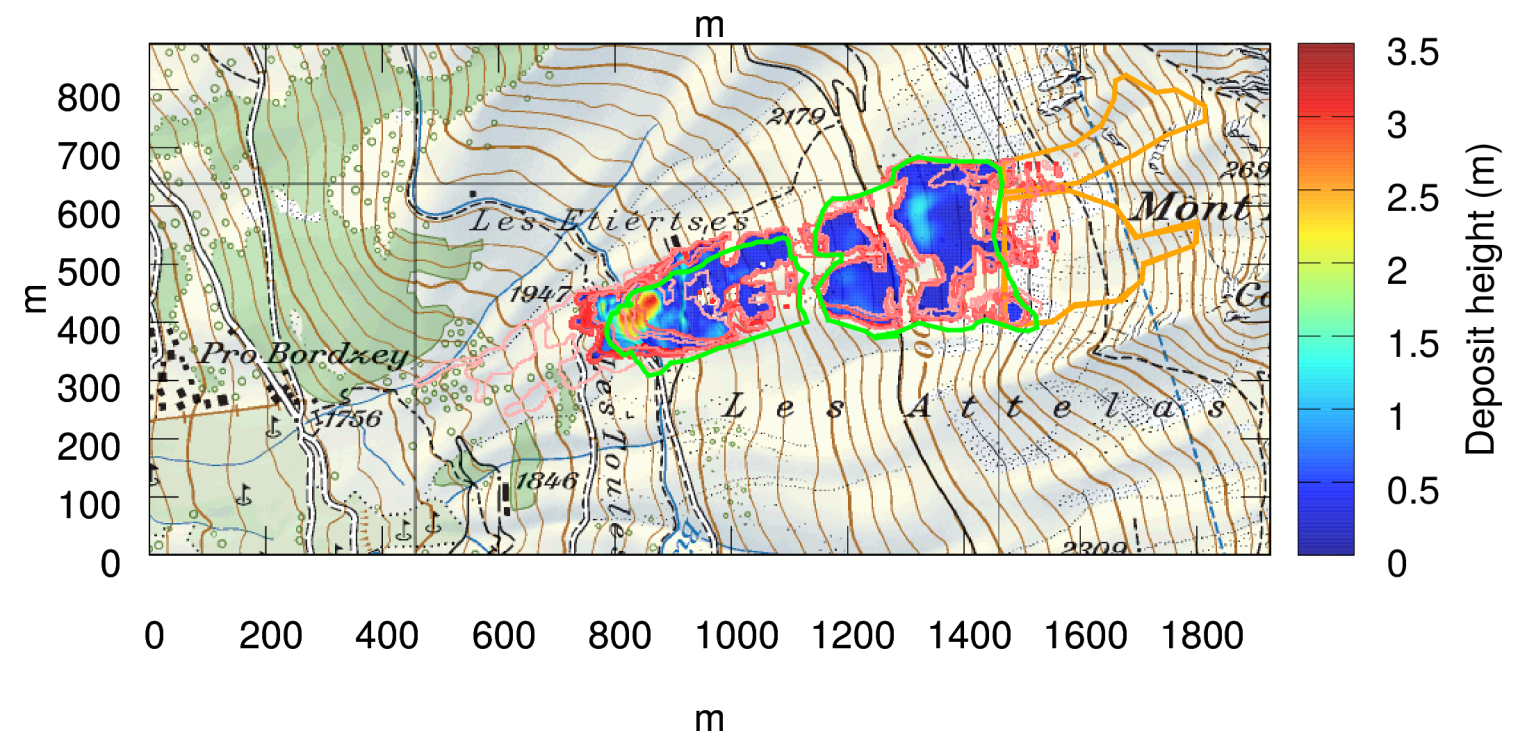

Figure S20: Mont Rogneux Verbie. For description see page 15.r 

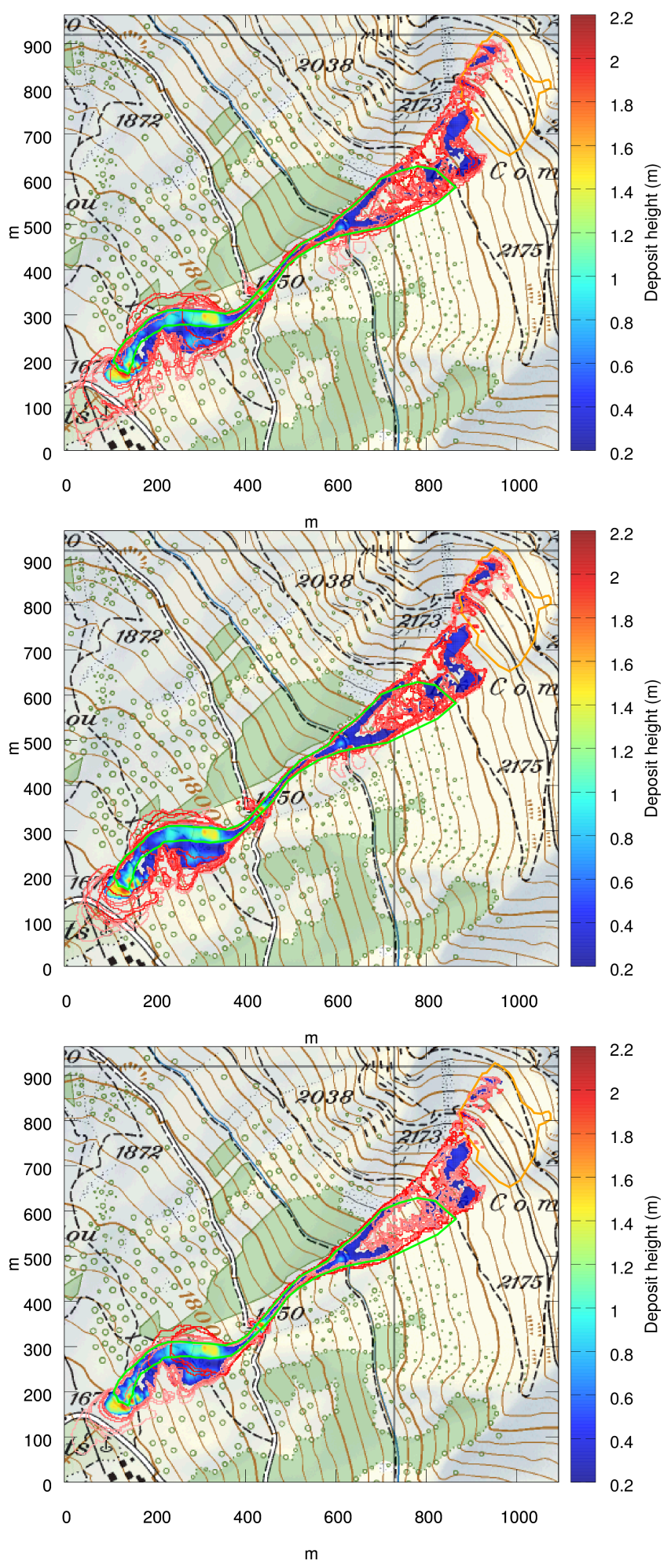

Figure S21: Ba Combe Verbier. For description see page 15. 

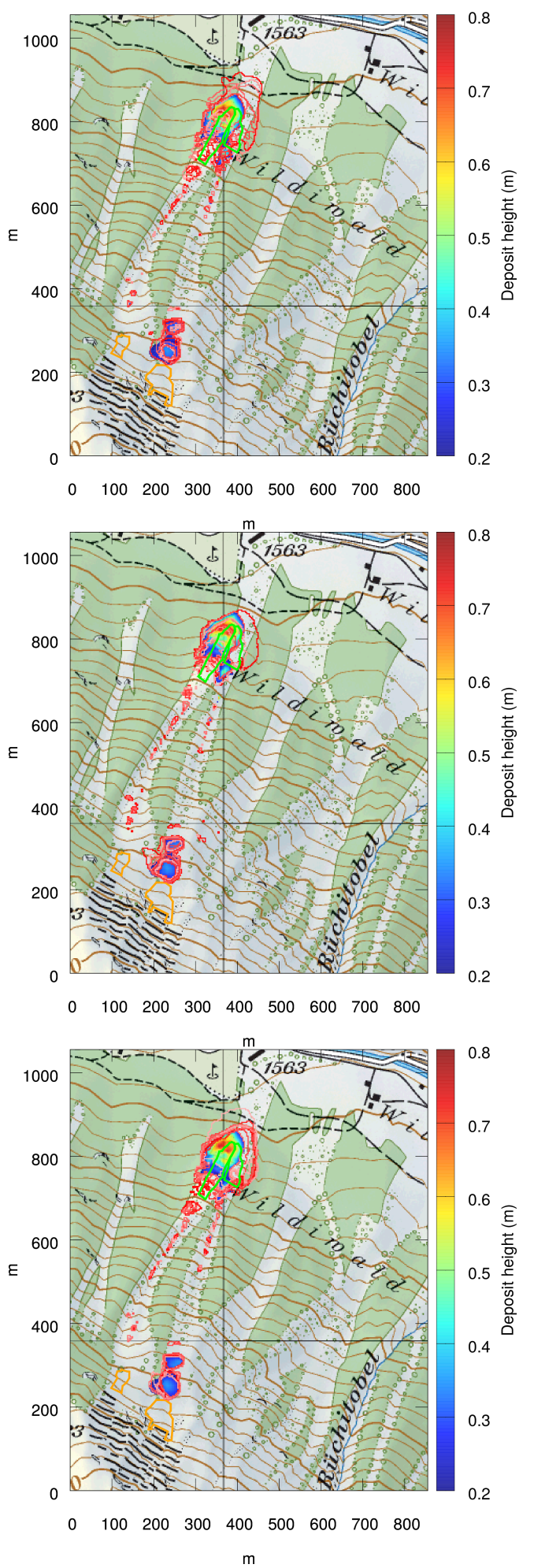

Figure S22: Braemabuhl Verbauung Davos 

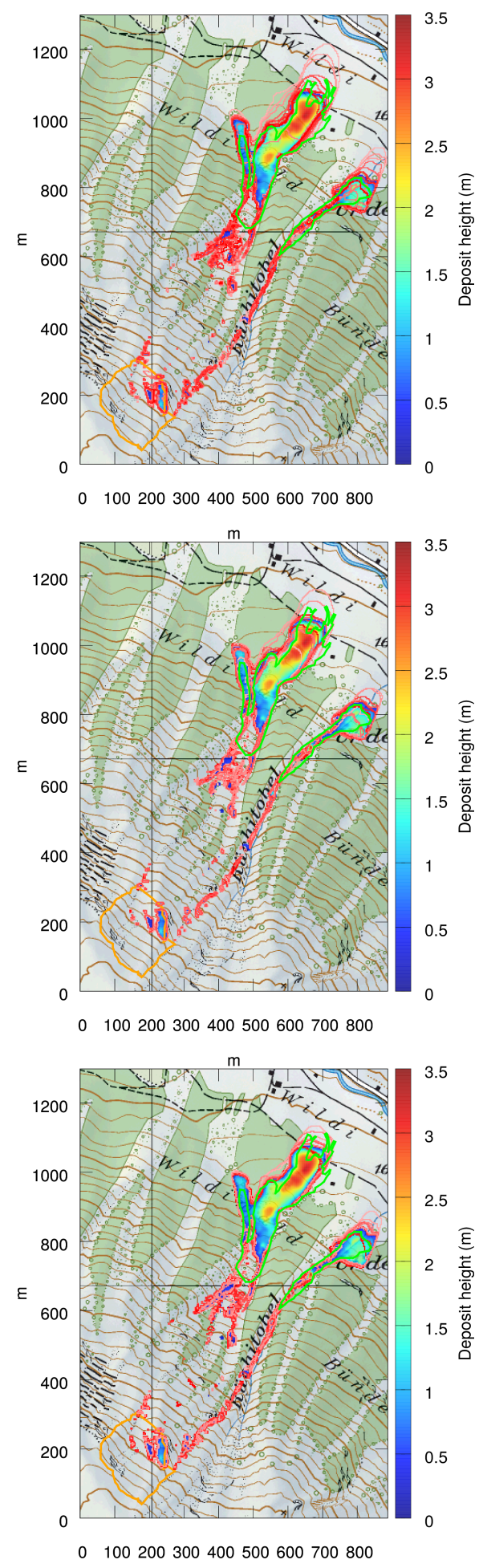

$\mathrm{m}$

Figure S23: Wildi Davos. For description see page 15. 

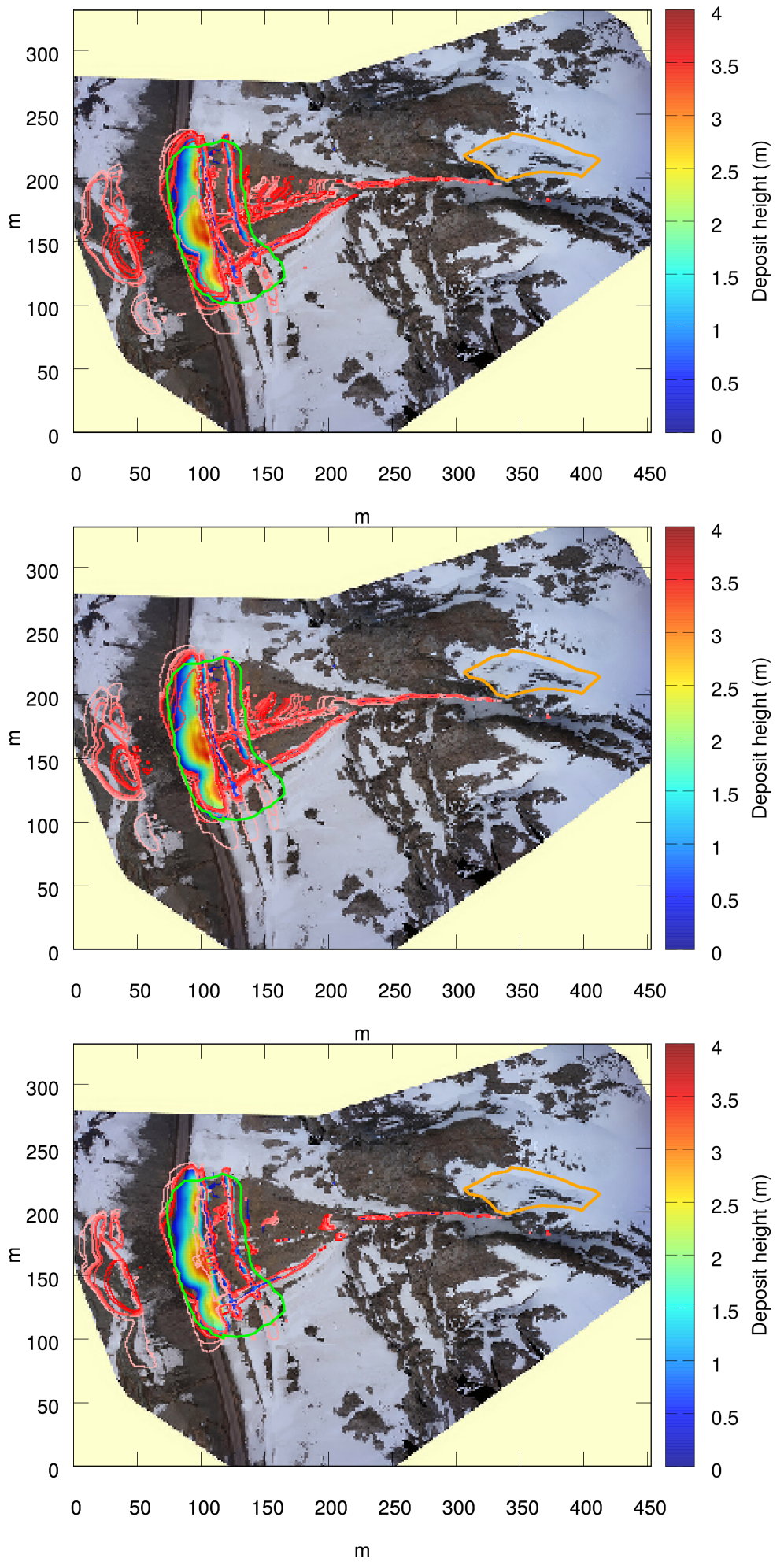

Figure S24: Codelco Andina Chile CV-1. For description see page 15. 